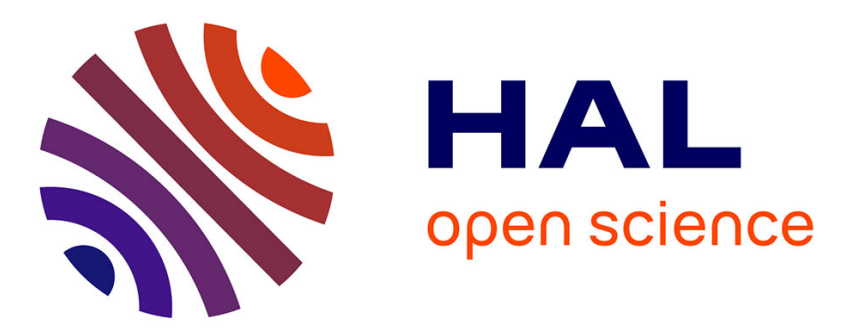

\title{
Abyssal ocean overturning shaped by seafloor distribution
}

Casimir de Lavergne, Gurvan Madec, Fabien Roquet, R. M. Holmes, Trevor J. Mcdougall

\section{- To cite this version:}

Casimir de Lavergne, Gurvan Madec, Fabien Roquet, R. M. Holmes, Trevor J. Mcdougall. Abyssal ocean overturning shaped by seafloor distribution. Nature, 2017, 551 (7679), pp.181 - 186. 10.1038/nature24472 . hal-03334723

\section{HAL Id: hal-03334723 \\ https://hal.science/hal-03334723}

Submitted on 8 Sep 2021

HAL is a multi-disciplinary open access archive for the deposit and dissemination of scientific research documents, whether they are published or not. The documents may come from teaching and research institutions in France or abroad, or from public or private research centers.
L'archive ouverte pluridisciplinaire HAL, est destinée au dépôt et à la diffusion de documents scientifiques de niveau recherche, publiés ou non, émanant des établissements d'enseignement et de recherche français ou étrangers, des laboratoires publics ou privés. 


\section{Abyssal ocean overturning shaped by seafloor distribution}

2

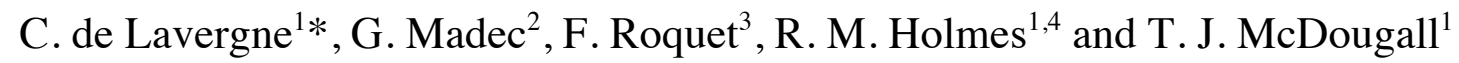

4

${ }^{1}$ School of Mathematics and Statistics, University of New South Wales, Sydney NSW 2052, 6 Australia

${ }^{2}$ LOCEAN Laboratory, Sorbonne Universités (Université Pierre et Marie Curie Paris 6)-CNRS8 IRD-MNHN, Paris F-75005, France

${ }^{3}$ Department of Meteorology (MISU), Stockholm University, 11418 Stockholm, Sweden

$10{ }^{4}$ Climate Change Research Centre and ARC Centre of Excellence for Climate System Science, University of New South Wales, Sydney NSW 2052, Australia

12

*To whom correspondence should be addressed; e-mail: casimir.delavergne@gmail.com 


\section{Abstract}

16 The abyssal ocean is broadly characterized by northward flow of the densest waters and southward flow of lighter waters above. Understanding what controls the strength and structure

18 of these inter-hemispheric flows, referred to as the abyssal overturning circulation, is key to quantifying the ocean's ability to store carbon and heat on timescales exceeding one century.

20 Here we show that, north of $32^{\circ} \mathrm{S}$, the depth distribution of the seafloor compels dense southernorigin waters to flow north below $\sim 4 \mathrm{~km}$ depth and to return south predominantly deeper than

$22 \quad 2.5 \mathrm{~km}$. Unless ventilated from the north, the overlying mid-depths $(1-2.5 \mathrm{~km})$ host comparatively weak mean meridional flow. Backed by a new analysis of historical radiocarbon

24 measurements, the findings imply that the geometry of the Pacific, Indian and Atlantic basins places a major external constraint on the overturning structure.

\section{Main text}

28 Dense waters originating from the surface at high latitudes make up the overwhelming majority of the ocean volume. Once formed through heat loss and salt gain, they sink to depth and spread

30 across the globe, carrying surface information into the slow-paced abyss and contributing to the long memory of the ocean ${ }^{1}$. But the memory time and climate buffering effect of the deep ocean

32 ultimately depend upon the rate at which these dense waters are removed from deep seas and returned to the surface. Physical controls on the volume and return pathways of dense waters are

34 therefore key to the ocean's carbon and heat storage capacity and its role in centennial to multimillennial climate variability ${ }^{2,3}$.

36 The cycle of production, modification and consumption of dense water masses is often conceptualized as a meridional overturning circulation composed of two dynamically distinct

$38 \operatorname{limbs}^{4,5}$ (Fig. 1a): an abyssal, northward limb that carries the densest Antarctic-sourced waters (Antarctic Bottom Water: AABW) until they upwell into lighter waters of the Indian, Pacific and

40 Atlantic basins; and a shallower, southward limb that carries these lighter deep waters to the Southern Ocean. Because it involves a gradual decrease in the density of AABW, the abyssal

42 branch is considered to be essentially a diabatic circulation. In contrast, the southward flow of overlying deep waters is thought to be predominantly adiabatic, that is, density-preserving ${ }^{6,7}$. This

44 dynamical divide is consistent with the two regimes apparent in the deep ocean density distribution (Fig. 1a): north of the Antarctic Circumpolar Current and away from polar sinking,

46 flat density surfaces above $\sim 2.5 \mathrm{~km}$ depth appear compatible with an adiabatic arrangement of water masses, whereas the northward descent of abyssal density surfaces signals transformation of AABW as it travels north. The transition between diabatic and adiabatic regimes, and the transition from northward to southward mass transport, have been linked to the depth profile of

50 basin-averaged mixing rates, and to surface wind forcing over the Southern Ocean ${ }^{3-8}$. Here we show that these two transitions are tied to the depth distribution of seafloor and are separate from each other.

The deep ocean communicates with the surface in two high-latitude regions (Fig. 1a): the North 54 Atlantic, where deep waters are formed and exported southward to ventilate the $27.7-28.14 \mathrm{~kg} \mathrm{~m}^{-3}$ density range ${ }^{9,10}$; and the Southern Ocean, where rising density surfaces allow deep waters to 56 upwell primarily adiabatically ${ }^{6,711,12}$ until they are converted into denser AABW or lighter 
intermediate and mode waters ${ }^{5}$. Note that we use neutral density ${ }^{13}$, denoted $\gamma$, as a globally consistent density variable and subtract $1,000 \mathrm{~kg} \mathrm{~m}^{-3}$ from all density values. Away from these regions, dense waters are isolated from surface exchanges: their density transformation and

60 upwelling rely on deep diabatic processes. We henceforth focus on such processes and restrict the analysis to ocean waters deeper than $1 \mathrm{~km}$ between $32^{\circ} \mathrm{S}$ and $48^{\circ} \mathrm{N}$.

62 Geometry. At depths of 1 to $2.5 \mathrm{~km}$, ocean topography is dominated by relatively steep continental slopes and accounts for less than $8 \%$ of the total seabed area (Fig. 2a,b). Deeper, the 64 emergence of flatter ridges decaying onto abyssal plains markedly increases the seafloor area per unit depth, which quadruples between 2.5 and $4.3 \mathrm{~km}$ depth. Depth layers therefore have unequal 66 access to the seafloor: the $1 / 4$ of the water volume which resides below $3.5 \mathrm{~km}$ occupies $3 / 4$ of the seabed. This inequality is reinforced when considering the seafloor coverage of density layers

68 - that is, layers defined by a fixed density interval - , because their thickness generally increases with depth in the deep ocean (Figs. 1 and 2c,d). By analogy with surface outcrop areas,

70 the seafloor area intersected by a given density layer is termed incrop area. The relatively narrow $28-28.25 \mathrm{~kg} \mathrm{~m}^{-3}$ density range takes up over $80 \%$ of the ocean floor between $32^{\circ} \mathrm{S}$ and $48^{\circ} \mathrm{N}$, the

72 lion's share going to $\sim 28.11 \mathrm{~kg} \mathrm{~m}^{-3}$ waters (Fig. 2c,d; see also Extended Data Fig. 1).

These simple geometric considerations have important implications for the consumption rate and 74 upwelling pathways of dense waters. Deep ocean sources of density transformation have long been recognized to be concentrated near the seafloor ${ }^{14-20}$, where boundary-catalysed turbulence

76 and geothermal heating combine to erode the near-bottom stratification and progressively lighten bottom seawaters. The resulting near-bottom confinement of density loss suggests that deep

78 water masses benefiting from a large seafloor coverage are more likely to be efficiently consumed than those isolated from the bottom. Consistent with the preferential lightening of

80 bottom boundary waters, incrop areas tend to increase along the northward path of AABW and to slowly migrate towards smaller densities (Fig. 1b), indicative of a successive removal of 82 incropping density layers and resultant homogenization of $\mathrm{AABW}^{21}$. The conjunction between the regime of sloping density surfaces and the presence of significant incrop areas (Figs. $1 \mathrm{~b}$ and

84 3b; Extended Data Figs. 2-4) is further suggestion of the dominant role of boundary transformation. Hence, the concentration of seafloor area around the $4-5.5 \mathrm{~km}$ and $28.11 \mathrm{~kg} \mathrm{~m}^{-3}$

86 levels may strongly influence the structure of cross-density transports and the associated meridional flows.

88 Water mass transformation. To formally relate overturning flows to incrop areas, we first set out the link between cross-density transport and the vertical profile of diffusive density fluxes.

90 Consider the volume $V(\gamma)$ of waters denser than $\gamma$, bounded by the seafloor, the density surface $A(\gamma)$ and latitudes $y_{s}<y_{n}$ (Fig. 4). We define the total geothermal and mixing-driven density

92 fluxes entering $V$ from below and from above as $G(\gamma)$ and $F(\gamma)$, respectively. For the volume $V$ to remain unchanged, advection across $A$ must balance local geothermal and mixing-driven density 94 tendencies, such that ${ }^{21-23}$

$$
T=\partial_{\gamma}(F+G),
$$

96 where $T(\gamma)$ denotes the mass transport through $A(\gamma)$ and is termed the dianeutral transport. Equation (1) states that the transport across a given density layer is proportional to the net geothermal and mixing-induced density change within that layer. Geothermal heating causes only 
lightening, balanced by dianeutral upwelling ( $T>0$, towards lower density). In contrast, mixing may be a density source or sink, requiring downwelling or upwelling, respectively.

Dianeutral transports are thus controlled by the $\gamma$-profile of the total density flux entering successively denser water volumes, $(F+G)(\gamma)$. In turn, we can relate basin-scale dianeutral transports to meridional, along-density flows by realizing that $T$ must equal the zonally-integrated meridional mass flux into $V$. Denoting by the streamfunction $\psi_{s}\left(\psi_{n}\right)$ the net southward mass transport through the $y_{s}\left(y_{n}\right)$ bounding latitude section of $V$ (Fig. 4), we have by continuity

$$
T=\psi_{n}-\psi_{s} .
$$

In the deep Indian and Pacific oceans, choosing $y_{n}$ at the closed northern end of each basin yields simply $T=-\psi_{s}$. This entails in particular that the density surface of peak dianeutral upwelling $T$ north of $y_{s}$ defines the boundary between northward and southward flow at $y_{s}$ (Figs. 3d and 4). In 110 the abyssal Atlantic, dianeutral upwelling may balance inflow from the south and north, so that the meridional flow reversal may lie at a denser level than the peak upwelling rate. Nonetheless,

112 we find the two levels to match in this basin as well when choosing $y_{n}=48^{\circ} \mathrm{N}$ (Fig. 4, Extended Data Fig. 4 and Methods).

114 Mixing scenarios. Fig. 5 shows the profile of the mixing-driven density flux $F$ as well as the associated $32^{\circ} \mathrm{S}-48^{\circ} \mathrm{N}$ dianeutral transports under two idealized scenarios (Methods): (s1) uniform

116 local density fluxes throughout the ocean interior; (s2) bottom-enhanced local density fluxes, with uniform bottom magnitude. The bottom-intensification of (s2) density fluxes is specified as

118 an exponential decay from the seafloor with a $500 \mathrm{~m}$ e-folding scale, a structure representative of turbulence observations in the abyssal Brazil Basin ${ }^{24}$. Flux magnitudes are chosen so that both 120 peak upwelling rates equal $25 \times 10^{6} \mathrm{~m}^{3} \mathrm{~s}^{-1}$, a mid-range estimate of maximum abyssal upwelling ${ }^{9,10,5}$ constrained by velocity measurements at circulation nodes ${ }^{25-29}$. Shadings show the

122 added contribution of a uniform mixing rate of $10^{-5} \mathrm{~m}^{2} \mathrm{~s}^{-1}$, a typical level of mixing away from the direct influence of boundaries ${ }^{14,30-33}$.

124 Scenario (s1) corresponds to a diabatic bottom boundary overlain by an adiabatic ocean interior: convergence of local density fluxes occurs only in the unstratified bottom boundary layer, where

126 the density flux weakens to satisfy a no-flux boundary condition - the constraint that turbulent mixing cannot flux density across the seafloor ${ }^{19,21,34,35}$. The implied density transformation and 128 dianeutral circulation are thus qualitatively identical to those that would be generated by a uniform geothermal density sink along the ocean bottom. The scenario results in diabatic 130 upwelling peaking at $\gamma=28.11 \mathrm{~kg} \mathrm{~m}^{-3}$ and mostly confined to below the $28 \mathrm{~kg} \mathrm{~m}^{-3}$ density surface, matching the incrop area distribution (Figs. 2c, $5 \mathrm{c}$ and 6). Indeed, since a uniform density flux

132 homogeneously lightens waters covering the ocean floor, scenario (s1) implies that density layers upwell in proportion to their access to the seafloor (Extended Data Fig. 5). Consequently,

134 diabatic upwelling is restricted to the depth and density range of significant incrop areas, and the boundary between northward and southward meridional transport is the density surface of

136 maximum incrop area (Fig. 6). In particular, most of the southern-origin dense waters must then flow back to the Antarctic Circumpolar Current deeper than $2.5 \mathrm{~km}$.

138 Because geothermal heat fluxes exhibit relatively weak spatial variations away from ridge crests and contribute only bottom density losses, their impact on circulation is well described by the uniform-flux idealization $(\mathrm{s} 1)^{23,21}$. In contrast, deep ocean mixing is observed to be dominated by 
patchy, topographically-enhanced turbulence $e^{15-17,19,36-38,32,33}$. Such turbulence is generally associated with a bottom-enhanced local density flux, whereby lightening of densest waters occurs at the expense of densification immediately above. Scenario (s2) explores the impact of an

144 idealized, geographically homogenous bottom-intensification of density fluxes. Under this scenario, density loss (gain) generally dominates for density layers that have a larger (smaller) incrop area than their underlying neighbour: the change in incrop area with height determines the dianeutral transport (Extended Data Fig. 5). Upwelling is consequently found within waters denser than $28.11 \mathrm{~kg} \mathrm{~m}^{-3}$, peaking just under this level, whereas density gain and downwelling characterize lighter waters (Fig. 5c). Hence, despite their structural difference (Fig. 5a,b), the

150 simple scenarios (s1) and (s2) share two essential features: the induced upwelling peaks near the density level of maximum seafloor coverage, and decreases rapidly at lighter densities.

152 The complex spatial patterns of deep ocean turbulence could override these features. Multiple lines of evidence indicate otherwise. First, examination of a range of bottom-intensified mixing 154 scenarios analogous to (s2), where the magnitude of local density-flux profiles is not uniform but instead depends on bottom roughness, slope, stratification or internal wave generation rates

156 (Methods), consistently shows upwelling peaking at or below the peak incrop surface and dwindling rapidly above (Extended Data Fig. 6). Second, consideration of local density fluxes

158 that decay above the bottom according to non-exponential and region-dependent profiles alters the distribution of density gain in the interior but preserves the near-bottom location of density

160 loss, leading to a coupling between incrop and upwelling profiles similar to that inherent in the scenarios (s1) and (s2). Third, turbulence remote from boundaries, fed by interactions among internal waves and associated with weakly varying mixing rates of order $10^{-5} \mathrm{~m}^{2} \mathrm{~s}^{-1}$ (refs. 14,3033 ), drives only weak upwelling deeper than $2.5 \mathrm{~km}$ (Fig. 5c, shadings). From 2.5 to $1 \mathrm{~km}$ depth,

164 the upwelling induced by a uniform $\mathrm{O}\left(10^{-5} \mathrm{~m}^{2} \mathrm{~s}^{-1}\right)$ diffusivity remains modest and fairly constant, demanding little net meridional flow.

166 Radiocarbon evidence. Fourth, analysis of historical radiocarbon measurements ${ }^{39,40}$ confirms the tight connection between incrop areas and the overturning structure (Fig. 3c; Extended Data Figs.

168 2-4). By mapping radiocarbon content $\left(\Delta^{14} C\right)$ along density surfaces (Methods), we find that: (i) the maximum incrop area accurately predicts the transition surface between northward and 170 southward flow identified in each basin's $\Delta{ }^{14} \mathrm{C}$ distribution; (ii) the height at which the incrop area falls to $10 \%$ of its peak approximates the lower boundary of the relatively thick $\Delta^{14} \mathrm{C}$ minimum (age maximum) observed at mid-depth in the Pacific and Indian oceans.

Because of its size and connectedness, the Pacific basin shows the clearest signature of seafloor areas on the radiocarbon distribution (Fig. 3). The strongest vertical $\Delta{ }^{14} \mathrm{C}$ gradient at $32^{\circ} \mathrm{S}$ occurs at the density of the basin's peak incrop area, $\gamma=28.11 \mathrm{~kg} \mathrm{~m}^{-3}$, where the inflow of relatively 176 young waters underlies their southward return after a centuries-long journey in the abyssal Pacific. Water mass transformation estimates (Fig. 5 and Extended Data Fig. 6) further indicate 178 that most of this southward return flow takes place below the $28 \mathrm{~kg} \mathrm{~m}^{-3}$ density surface, the transitional level above which seafloor availability becomes scarce (Figs. 2 and 3a,b). The 180 minimum $\Delta^{14} \mathrm{C}$ centred around $2.3 \mathrm{~km}\left(\gamma=27.95 \mathrm{~kg} \mathrm{~m}^{-3}\right)$ must then reflect weak upwelling of bottom waters to that depth. This inference is corroborated by the correspondence between the

182 structure of the $\Delta^{14} \mathrm{C}$ minimum and the depth or density distribution of seafloor areas (Fig. 3 and Extended Data Figs. 2 and 3): oldest density layers appear to be those largely isolated from the ocean bottom and, thereby, from renewal via abyssal upwelling. 
The Atlantic and Indian oceans host more complex AABW pathways due to their compartmentalisation into many subbasins. There, the leading role of inter-basin passages in transforming the northward-flowing AABW is clearly demonstrated by the bottom density field

188 (Extended Data Fig. 1). Indeed, substantial density drops from subbasin to subbasin largely reflect concentrated mixing within connecting AABW throughflows ${ }^{16,29,36}$. Such concentrated 190 density transformation suggests that the access to constrictive passages could be as strong a determinant of diabatic upwelling rates as is the access to large seafloor areas. However,

192 radiocarbon distributions show that abyssal circulation chokepoints do not host the peak dianeutral transports that define the meridional flow reversal (Methods and Extended Data Figs. 3

194 and 4). Instead, deep straits and sills appear to reinforce the influence of incrop areas on the overall overturning structure: by contributing prominently to the homogenization of AABW, they

196 favour the concentration of incrop areas to a narrow density range and the pivotal upwelling of end-basin waters ${ }^{36}$ (Methods).

198 Hence, water mass transformation scenarios and modern radiocarbon distributions together show that diabatic upwelling peaks near the density layer that has the largest seafloor coverage and 200 decreases rapidly at lighter densities. The robustness of this structure owes to two principal facts: (i) boundary mixing and geothermal heating restrict density loss to the bottom boundary; and (ii) 202 density layers have strongly unequal access to the seafloor. Fact (ii) is firstly a consequence of the concentration of seafloor at depths greater than $2.5 \mathrm{~km}$ (Figs. 2 and 3a,b; Extended Data Figs.

204 2-4). It is further reinforced by fact (i), which underpins the progressive focusing of AABW into its lighter classes that monopolize the floor of northern basins ${ }^{21,36}$, and which favours the 206 northward spreading of abyssal density surfaces ${ }^{8}$ (Fig. 1b). Boundary-dominated transformation and the depth distribution of seafloor thus collude to shape an incrop area profile which peaks 208 deeper than $4 \mathrm{~km}$ and decays to small values near $2.5 \mathrm{~km}$ depth. This collusion accentuates the segregation of water masses situated below and above the $2.5 \mathrm{~km}$ geopotential, and suggests that

210 the main patterns of incrop area and upwelling diagnosed from the modern hydrography must hold across a broad range of ocean states.

212 Implications of these patterns for the functioning of the meridional overturning north of $32^{\circ} \mathrm{S}$ can be summarized as follows (Figs. 2 and 6): (i) strong upwelling (or downwelling) rates define a

214 diabatic deep ocean regime at depths greater than $2.5 \mathrm{~km}$, where most of the seabed lies; (ii) an overlying adiabatic regime, within 1-2.5 km depth, hosts non-negligible mixing but

216 comparatively limited dianeutral transports; (iii) northward-flowing dense waters reside below the density layer with greatest access to the seabed, thus largely below $4 \mathrm{~km}$ depth, where

218 seafloor availability is maximal; (iv) the majority of dense southern-origin waters returns southward within the diabatic regime, below $2.5 \mathrm{~km}$ depth. The first two conclusions rely

220 essentially on the knowledge of the ocean bathymetry and could potentially be recast for a different depth distribution of seafloor. The latter two further assume a southern origin of the 222 densest global-scale water mass.

Conclusion (iv) entails that the circulation of dense Antarctic-origin waters in the Pacific and 224 Indian basins is more compressed in the vertical than has been inferred in most inverse box models $^{9,10,5}$, despite limited consistency among these inverse solutions (see discussions of Pacific

226 and Indian abyssal pathways in the Methods). The depth profile of the southward return flow at $32^{\circ} \mathrm{S}$ implied by idealized water mass transformation scenarios is also variable (Fig. 5c and

228 Extended Data Fig. 6), reflecting the lack of constraints on the global mixing distribution. These 
uncertainties and discrepancies call for further work to refine and reconcile different estimates of 230 the abyssal overturning structure. Examining the silicic acid $\left(\mathrm{Si}(\mathrm{OH})_{4}\right)$ distributions ${ }^{41}$ of the Pacific and Indian oceans, we find additional support for a relatively deep southward return flow

232 (Extended Data Fig. 7). In the northern part of the two basins, where deep $\mathrm{Si}(\mathrm{OH})_{4}$ production is thought to be more intense and largely placed at the sediment-water interface $e^{42-45}$, vertical maxima

234 of $\mathrm{Si}(\mathrm{OH})_{4}$ lie immediately above the depth range of large seafloor areas ${ }^{46}$. This concurs with relatively strong circulation and short residence times limiting $\mathrm{Si}(\mathrm{OH})_{4}$ accumulation within this

236 depth range. Further south, the maxima shift towards larger densities falling within the diabatic regime, consistent with southward mean flow promoting the export of $\mathrm{Si}(\mathrm{OH})_{4}$ there. This latter

238 feature is not visible in the eastern Indian ocean, but the radiocarbon structure of this subbasin clearly substantiates a geometric confinement of its abyssal overturning to depths greater than 3.7

$240 \mathrm{~km}$ (Extended Data Fig. 3 and Methods).

The seafloor area distribution, generally absent from conceptual models or quantitative theories

242 of the overturning, thus exerts major constraints on the volumes, pathways and interplay of dense water masses. In particular, within basins receiving only a southern influx of ventilated dense

244 waters, the abyssal concentration of seafloor implies a partial disconnect between a relatively well-ventilated abyss and more stagnant mid-depth waters. Accordingly, we propose that present-

246 day Pacific and Indian waters straddling the mid-depth radiocarbon minimum do not embody returning $\mathrm{AABW}$ but rather lie in a shadow zone of the overturning (Figs. 3d and 6),

248 characterized by its isolation from surface and bottom boundary influences, and traversed by relatively weak mean meridional flow. The larger volume and longer residence time of shadow

250 zone waters relative to the underlying diabatic abyss make them a stronger candidate for lasting property storage. Yet an active northern surface source of deep water, as occurs in today's 252 Atlantic and could have occurred in the Pacific ${ }^{47,48}$, may disrupt the mid-depth stores, and reduce the volume and influence of the dense southern-origin waters.

\section{References}

256 1. Primeau, F. W. \& Holzer, M. The ocean's memory of the atmosphere: residence-time and ventilation-rate distributions of water masses. J. Phys. Oceanogr. 36, 1,439-1,456 (2006).

258 2. Sarmiento, J. L. \& Toggweiler, J. R. A new model for the role of the oceans in determining atmospheric $\mathrm{pCO}_{2}$. Nature 308, 621-624 (1984).

260 3. Ferrari, R. et al. Antarctic sea ice control on ocean circulation in present and glacial climates. Proc. Nat. Acad. Sci. 111, 8,753-8,758 (2014).

262 4. Nikurashin, M. \& Vallis, G. A theory of the interhemispheric meridional overturning circulation and associated stratification. J. Phys. Oceanogr. 42, 1,652-1,667 (2012).

264 5. Talley, L. D. Closure of the global overturning circulation through the Indian, Pacific, and Southern Oceans: schematics and transports. Oceanogr. 26, 80-97 (2013).

266 6. Toggweiler, J. R. \& Samuels, B. New Radiocarbon Constraints on the Upwelling of Abyssal Water to the Ocean's Surface. NATO ASI Series, ed Heimann M (Springer, Berlin), pp 303-331 268 (1993). 
7. Toggweiler, J. R. \& Samuels, B. On the ocean's large-scale circulation near the limit of no vertical mixing. J. Phys. Oceanogr. 28, 1,832-1,852 (1998).

8. Mashayek, A., Ferrari, R., Nikurashin, M. \& Peltier, W. R. Influence of enhanced abyssal 272 diapycnal mixing on stratification and the ocean overturning circulation. J. Phys. Oceanogr. 45, 2,580-2,597 (2015).

274 9. Ganachaud, A. \& Wunsch, C. Improved estimates of global ocean circulation, heat transport and mixing from hydrographic data. Nature 408, 453-458 (2000).

276 10. Lumpkin, R. \& Speer, K. Global ocean meridional overturning. J. Phys. Oceanogr. 37, 2,550$2,562(2007)$.

278 11. Marshall, D. Subduction of water masses in an eddying ocean. J. Mar. Res. 55, 201-222 (1997).

280 12. Marshall, J. \& Speer, K. Closure of the meridional overturning circulation through Southern Ocean upwelling. Nat. Geosci. 5, 171-180 (2012).

282 13. Jackett, D. R. \& McDougall, T. J. A neutral density variable for the world's oceans. J. Phys. Oceanogr. 27, 237-263 (1997).

284 14. Ledwell, J. R., Watson, A. J. \& Law, C. S. Evidence for slow mixing across the pycnocline from an open-ocean tracer-release experiment. Nature 364, 701-703 (1993).

286 15. Toole, J. M., Polzin, K. L \& Schmitt, R. W. Estimates of diapycnal mixing in the abyssal ocean. Science 264, 1,120-1,123 (1994).

288 16. Polzin, K. L., Speer, K. G., Toole, J. M. \& Schmitt, R. W. Intense mixing of Antarctic Bottom Water in the equatorial Atlantic ocean. Nature 380, 54-57 (1996).

290 17. Polzin, K. L., Toole, J. M., Ledwell, J. R. \& Schmitt, R. W. Spatial variability of turbulent mixing in the abyssal ocean. Science 276, $93-96$ (1997).

292 18. Munk, W. \& Wunsch, C. Abyssal recipes II: energetics of tidal and wind mixing. Deep-Sea Res. 45, 1,977-2,000 (1998).

294 19. Ledwell, J. R. et al. Evidence for enhanced mixing over rough topography in the abyssal ocean. Nature 403, 179-182 (2000).

296 20. Adcroft, A., Scott, J. R. \& Marotzke, J. Impact of geothermal heating on the global ocean circulation. Geophys. Res. Lett. 28, 1,735-1,738 (2001).

298 21. de Lavergne, C., Madec, G., Le Sommer, J., Nurser, A. J. G. \& Naveira Garabato, A. C. On the consumption of Antarctic Bottom Water in the abyssal ocean. J. Phys. Oceanogr. 46, 635-661 300 (2016).

22. Walin, G. On the relation between sea-surface heat flow and thermal circulation in the ocean.

Tellus 34A, 187-195 (1982). 
23. Emile-Geay, J. \& Madec, G. Geothermal heating, diapycnal mixing and the abyssal circulation. Ocean Sci. 5, 203-217 (2009).

24. St. Laurent, L. C., Simmons, H. L. \& Jayne, S. R. Estimating tidally driven mixing in the 306 deep ocean. Geophys. Res. Lett. 29, 2,106 (2002).

25. Roemmich, D., Hautala, S. \& Rudnick, D. Northward abyssal transport through the Samoan passage and adjacent regions. J. Geophys. Res. 101, 14,039-14,055 (1996).

26. Whitworth III, T. et al. On the deep western-boundary current in the southwest Pacific basin. 310 Progr. Oceanogr. 43, 1-54 (1999).

27. Hogg, N. G., Siedler, G. \& Zenk, W. Circulation and variability at the southern boundary of the Brazil Basin. J. Phys. Oceanogr. 29, 145-157 (1999).

28. Schott, F. A. et al. The shallow and deep western boundary circulation of the South Atlantic at $5^{\circ}-11^{\circ}$ S. J. Phys. Oceanogr. 35, 2,031-2,053 (2005).

29. MacKinnon, J. A., Johnston, T. M. S. \& Pinkel, R. Strong transport and mixing of deep water through the Southwest Indian Ridge. Nat. Geosci. 1, 755-758 (2008).

30. Gregg, M. C. Scaling turbulent dissipation in the thermocline. J. Geophys. Res. 94, 9,686$3189,698(1989)$.

31. Polzin, K. L., Toole, J. M. \& Schmitt, R. W. Finescale parameterizations of turbulent dissipation. J. Phys. Oceanogr. 25, 306-328 (1995).

32. Waterhouse, A. F. et al. Global patterns of diapycnal mixing from measurements of the turbulent dissipation rate. J. Phys. Oceanogr. 44, 1,854-1,872 (2014).

33. Kunze, E. Internal-wave-driven mixing: global geography and budgets. J. Phys. Oceanogr. 47, 1,325-1,345 (2017).

34. Ferrari, R., Mashayek, A., McDougall, T. J., Nikurashin, M., Campin, J.-M. Turning ocean mixing upside down. J. Phys. Oceanogr. 46, 2,239-2,261 (2016).

35. McDougall, T. J. \& Ferrari, R. Abyssal upwelling and downwelling driven by near-boundary mixing. J. Phys. Oceanogr. 47, 261-283 (2017).

36. Bryden, H. L. \& Nurser, A. J. G. Effects of strait mixing on ocean stratification. J. Phys. 330 Oceanogr.33, 1,870-1,872 (2003).

37. Thurnherr, A. M., St. Laurent, L. C., Speer, K. G., Toole, J. M. \& Ledwell, J. R. Mixing associated with sills in a canyon on the midocean ridge flank. J. Phys. Oceanogr. 35, 1,370-1,381 (2005).

334 38. St. Laurent, L. C. \& Thurnherr, A. M. Intense mixing of lower thermocline water on the crest of the Mid-Atlantic Ridge. Nature 448, 680-683 (2007). 

ORNL/CDIAC-162, NDP-093, Carbon Dioxide Information Analysis Center, Oak Ridge 338 National Laboratory, US Department of Energy, Oak Ridge, Tennessee (2016).

40. Olsen, A. et al. The global ocean data analysis project version 2 (GLODAPv2) - an internally consistent data product for the world ocean. Earth Syst. Sci. Data 8, 297-323 (2016).

41. Gouretski, V. V. \& Koltermann, K. P. WOCE global hydrographic climatology: a technical report. Berichte des Bundesamtes für Seeschifffahrt und Hydrographie 35/2004, 52 pp (2004).

42. Sarmiento, J. L. et al. Deep ocean biogeochemistry of silicic acid and nitrate. Global Biogeochem. Cycles 21, GB1S90 (2007).

43. Dunne, J. P., Sarmiento, J. L. \& Gnanadesikan, A. A synthesis of global particle export from 346 the surface ocean and cycling through the ocean interior and on the seafloor. Global Biogeochem. Cycles 21, GB4006 (2007).

348 44. Tréguer, P. J. \& De La Rocha, C. L. The world ocean silica cycle. Annu. Rev. Mar. Sci. 5, 477-501 (2013).

350 45. Holzer, M., Primeau, F. W., DeVries, T. \& Matear, R. The Southern Ocean silicon trap: dataconstrained estimates of regenerated silicic acid, trapping efficiencies, and global transport paths.

352 J. Geophys. Res. 119, 313-331 (2014).

46. Talley, L. D. \& Joyce, T. M. The double silica maximum in the North Pacific. J. Geophys. 354 Res. 97, 5,465-5,480 (1992).

47. Okazaki, Y. et al. Deepwater formation in the North Pacific during the last glacial termination. 356 Science 329, 200-204 (2010).

48. Rae, J. W. B. et al. Deep water formation in the North Pacific and deglacial $\mathrm{CO}_{2}$ rise. Paleoceanography 29, 645-667 (2014).

49. Smith, W. H. F. \& Sandwell, D. T. Global sea floor topography from satellite altimetry and ship depth soundings. Science 277, 1,956-1,962 (1997).

\section{Acknowledgements}

We thank P. Barker and J. Dunn for their help with the mapping and for providing the distance 364 look-up tables. We also thank J. Nycander, A. Melet, M. Nikurashin and J. Goff for sharing their published datasets. C. de L., R. H. and T. McD. gratefully acknowledge Australian Research Council support through grant FL150100090.

\section{Author contributions}

C. de L. designed and conducted the analysis. All authors contributed to the writing and to the scientific interpretation of results. 


\section{Author information}

Reprints and permissions information is available at www.nature.com/reprints. The authors declare no competing financial interests. Correspondence and requests for materials should be addressed to C. de L. (casimir.delavergne@gmail.com).

\section{Figure legends}

Figure 1: Density surfaces, seafloor areas and the ocean's overturning. Climatologies ${ }^{41,49}$ of (a) neutral density and (b) zonally-summed incrop areas (units of $\mathrm{m}^{2}$ per latitude degree and per $\mathrm{kg} \mathrm{m}^{-3}$ ) as a function of latitude and pseudo-depth. The pseudo-depth of density surfaces is found by filling each latitude band from the bottom up with ocean grid cells ordered from dense to light. Grey arrows in a give a simplified view of overturning flows. Flows oriented along (across) density surfaces correspond to adiabatic (diabatic) transports. This study focuses on the latitude range $32^{\circ} \mathrm{S}-48^{\circ} \mathrm{N}$ enclosed in white lines.

Figure 2: Depth and density distributions of seafloor area over $32^{\circ} \mathrm{S}-48^{\circ} \mathrm{N}$. a,c, Seafloor area per unit (a) depth or (c) density. The mean density of geopotential surfaces and the mean depth of density surfaces are indicated on the left y-axis of a and $\mathbf{c}$, respectively. b,d, Bottom-up cumulative seafloor area as a function of (b) depth or (d) density. Lower and upper white lines depict respectively the northward-southward and diabatic-adiabatic transition levels tied to the seafloor distribution, as proposed in this study. Spreading ridges and abyssal plains dominate topography deeper than $2.5 \mathrm{~km}$; steep continental slopes dominate at smaller depths. Northwardflowing AABW dominates waters deeper than $4.3 \mathrm{~km}$ (denser than $28.11 \mathrm{~kg} \mathrm{~m}^{-3}$ ); its southward return as relatively dense Pacific Deep Water (PDW), Indian Deep Water (IDW) or North Atlantic Deep Water (NADW) occurs predominantly at depths greater than $2.5 \mathrm{~km}$ (densities greater than $\left.28 \mathrm{~kg} \mathrm{~m}^{-3}\right)$.

Figure 3: Pacific seafloor and radiocarbon distributions. a, Zonally-summed seafloor areas as a function of latitude and depth. $\mathbf{b}$, Zonally-summed incrop areas as a function of latitude and pseudo-depth. c, Along-density zonal mean radiocarbon content $\left(\Delta^{14} \mathrm{C}\right)$ as a function of latitude and pseudo-depth. d, Schematic regime transitions, as in Fig. $2 b, d$. The pseudo-depth of density surfaces is defined as in Fig. 1. Lower and upper white curves depict respectively the local northward-southward and diabatic-adiabatic transition levels inferred from the incrop area distribution. Specifically, at each latitude $y_{s}$, we calculate the $\gamma$-profile of summed incrop areas north of $y_{s}$. The northward-southward transition then corresponds to the density of the profile peak, while the diabatic-adiabatic transition is defined as the smallest density at which the incrop profile decreases to $10 \%$ of its peak. This figure includes the light blue region shown in the inset map in a, which hosts the main Pacific abyssal overturning (Methods). The full Pacific and southeastern Pacific are shown in Extended Data Fig. 2.

Figure 4: Sketch of a volume $V$ of waters denser than $\gamma$, bounded by the density surface $\boldsymbol{A}(\boldsymbol{\gamma})$ and latitudes $\boldsymbol{y}_{s}$ and $\boldsymbol{y}_{\boldsymbol{n}}$. Density fluxes $F$ and $G$ entering $V$ and the dianeutral mass transport $T$ leaving $V$ are also sketched. The streamfunctions $\psi_{s}(\gamma)$ and $\psi_{n}(\gamma)$ are defined as the net 
southward mass transport below $A(\gamma)$ at $y_{s}$ and $y_{n}$, respectively. As an illustrative example, we show (dotted line) the surface of (grey arrow) peak dianeutral upwelling. Mass conservation requires that this density surface corresponds to meridional flow reversal at $y_{s}$ (see velocity

414 arrows on the left) if: (i) the along-density transport at $y_{n}$ is zero, as is the case of the Pacific and Indian basins given $y_{n}$ at their northern end; or (ii) the along-density transport at $y_{n}$ is both

416 southward and weak below the peak upwelling level, as we infer to be the case of the western Atlantic given $y_{n}=48^{\circ} \mathrm{N}$ (Methods).

418 Figure 5: Density fluxes and dianeutral transports within $32^{\circ} \mathbf{S}-48^{\circ} \mathrm{N}$. Density profiles of (a) the total density flux $F$, (b) the density flux averaged over density surfaces and (c) total 420 dianeutral transports $T$ under (orange) scenario (s1) and (blue) scenario (s2). Shadings denote the added contribution to fluxes and transports of a uniform mixing rate of $10^{-5} \mathrm{~m}^{2} \mathrm{~s}^{-1}$.

422 Figure 6: Schematic abyssal overturning circulation north of $32^{\circ} \mathrm{S}$. The average depth of density surfaces is shown as a function of (lower axis) bottom neutral density and (upper axis)

424 cumulative seafloor area. The surface of maximum incrop area $\left(\gamma=28.11 \mathrm{~kg} \mathrm{~m}^{-3}\right)$, corresponding to meridional flow reversal, and the surface marking the approximate transition between diabatic 426 and adiabatic flow regimes $\left(\gamma=28 \mathrm{~kg} \mathrm{~m}^{-3}\right)$, are contoured in white. Straight and wiggly red arrows depict mixing-driven and geothermal buoyancy $(-\gamma)$ fluxes, respectively. To simplify the 428 illustration, mixing-driven fluxes are taken to be uniform in the vertical, as in scenario (s1). Density loss and diabatic upwelling are confined to near-bottom waters, which climb across 430 density surfaces and along topography at a rate commensurate with the incrop area. Through mass conservation, this cross-density, along-bottom circulation maintains an along-density, 432 interior circulation which supplies (returns) dense waters from (to) the Antarctic Circumpolar Current. Note that in the Atlantic these along-density flows may have an additional supply

434 component from the subpolar North Atlantic. In the Indo-Pacific, a weakly-ventilated shadow zone lies above the abyssal overturning circulation in the approximate $1-2.5 \mathrm{~km}$ depth range.

\section{Methods}

438 Dianeutral transports. Water mass transformation estimates presented in Fig. 5 and Extended Data Fig. 6 use the global neutral density field of the WOCE hydrographic climatology ${ }^{41}$. In 440 scenarios (s1), (s2) and the scenarios of Extended Data Fig. 6, the specified three-dimensional map of neutral density fluxes allows us to calculate the total density flux $F$ through each density

442 surface $A(\gamma)$. The density derivative of $F$ then yields the dianeutral transport $T$ as per equation (1). The contribution of a fixed diffusivity illustrated by shadings in Fig. 5 is obtained through the

444 same procedure. Uncertainty in the obtained transport profiles reflects mostly the incomplete spatial coverage of the hydrographic observations that underlie the WOCE climatology and the

446 limited horizontal and vertical resolution of the climatology. In spite of these limitations, substantial errors in the basin-scale structure of density fluxes and dianeutral transports discussed 448 here are not expected ${ }^{21}$.

Sources of near-bottom turbulence, such as the breaking of internal waves ${ }^{50}$ or the generation of submesoscale instabilities ${ }^{51,52}$, depend on local flow, topography and stratification conditions. In particular, topographic roughness, topography scales and bottom stratification enter scalings for the rates of bottom internal wave generation ${ }^{53,54}$. In addition, the presence of steep slopes or 
small-scale topographic features may catalyse near-bottom turbulence ${ }^{51,52,55-57}$. To explore the influence of these parameters, in Extended Data Fig. 6 we examine variations of the bottomintensified mixing scenario (s2) by setting the magnitude of local density-flux profiles proportional to the: large-scale topographic slope squared; large-scale topographic roughness; small-scale topographic roughness ${ }^{58}$; horizontal wavenumber of small-scale topography ${ }^{58}$; bottom buoyancy frequency; squared bottom buoyancy frequency; internal tide generation rate ${ }^{59,60}$; lee wave generation rate ${ }^{61}$. Roughness is defined as the variance of bathymetric height. Large-scale 460 slopes and roughness are obtained by fitting planes over half-degree grid squares to the $1 / 30^{\circ}$ resolution etopo $2 \mathrm{v} 2$ bathymetry product ${ }^{49}$. Small-scale abyssal hills are not resolved by this 462 product. To account for these we use the small-scale roughness and wavenumber parameters estimated by ref. 58. In all eight cases, the average magnitude of the fluxes is adjusted to obtain a 464 maximum upwelling rate of $25 \times 10^{6} \mathrm{~m}^{3} \mathrm{~s}^{-1}$. Only the structure of transports thus warrants interpretation. Extended Data Fig. 6 shows that, irrespective of the scenario, dianeutral upwelling 466 is maximum at or below $\gamma=28.11 \mathrm{~kg} \mathrm{~m}^{-3}$, is weak or negative at $\gamma=28 \mathrm{~kg} \mathrm{~m}^{-3}$, and remains modest across the overlying regime of small incrop areas.

468 Radiocarbon maps. Radiocarbon content $\left(\Delta^{14} \mathrm{C}\right.$, expressed in per mil) corresponds to the deviation of the measured ${ }^{14} \mathrm{C} /{ }^{12} \mathrm{C}$ ratio relative to an atmospheric reference ratio, correcting for 470 isotopic fractionation ${ }^{62}$. At leading order, the evolution of $\Delta^{14} \mathrm{C}$ in the deep ocean is governed by advective-diffusive processes and radioactive decay of about $-10 \%$ every 83 years ${ }^{63,64}$. Mixing 472 affects the deep $\Delta{ }^{14} \mathrm{C}$ distribution through both its impact on circulation and the direct diffusive redistribution of radiocarbon ${ }^{64,65}$. The latter effect dominates in particular when significant 474 divergence of diffusive ${ }^{14} \mathrm{C}$ fluxes coexists with weak divergence of diffusive density fluxes: mixing along density surfaces - an important process controlling the $\Delta^{14} \mathrm{C}$ distribution ${ }^{66}-$ or 476 depth-independent density fluxes are cases in point.

We consider all $\Delta{ }^{14} \mathrm{C}$ values assembled in the GLODAPv2 data product ${ }^{39,40}$ and pair these with $\gamma$ values derived from corresponding hydrographic casts. The $2 \%$ of $\Delta{ }^{14} \mathrm{C}$ measurements (891 out of 36,541 measurements) for which concurrent hydrographic parameters are not available are assigned the $\gamma$ value of the corresponding position in the WOCE climatology. Next, each $\Delta \Delta^{14} \mathrm{C}$ cast is vertically interpolated onto a fixed series of $140 \gamma$ surfaces using a piecewise cubic 482 Hermite interpolating polynomial. We then map $\Delta{ }^{14} \mathrm{C}$ along each $\gamma$ surface independently. Grid point values are obtained as a weighted average of neighbouring measurements, the selection and

484 weighting of which rely on the distance look-up table described at http://www.marine.csiro.au/ dunn/cars2009/DLU/. Specifically, weights are defined as ${ }^{67,68}(1-$

$\left.486(r / 1,200 \mathrm{~km})^{3}\right)^{3}$, with $r$ the shortest path from the mapped grid point to surrounding data points at the grid point depth, bypassing topographic obstacles. Only data points whose distance $r$ to the 488 mapped grid point is less than 1,200 km are retained in each weighted average. The resulting global three-dimensional (longitude,latitude, $\gamma$ ) radiocarbon field is then plotted as a zonal 490 average in Fig. 3 and Extended Data Figs. 2-4 using the pseudo-depth reprojection described in the caption of Fig. 1. In Extended Data Fig. 8, we show an example map of $\Delta^{14} \mathrm{C}$ at $\gamma=28.045 \mathrm{~kg}$ $492 \mathrm{~m}^{-3}$, together with the underlying observations.

Uncertainty in the constructed maps originates from: the individual $\Delta^{14} \mathrm{C}$ measurement error, 494 estimated as $\pm 4 \%$ (ref. 69); errors in concurrent neutral density values; the limited spatiotemporal coverage of $\Delta^{14} \mathrm{C}$ measurements; and limitations of the mapping procedure. Given the 496 sparse observational coverage, uncertainties relate primarily to the sampling density, which is 
lowest in the southeastern Pacific, the western Indian and the eastern Atlantic oceans (Extended 498 Data Fig. 8b). The search radius of $1,200 \mathrm{~km}$ allows the vast majority of the ocean to be mapped, but smooths out smaller scale structures that may be present in the data. Note also that the 500 presented radiocarbon maps do not correct for the bomb-produced ${ }^{14} \mathrm{C}$, nor for any source of temporal variability of $\Delta{ }^{14} \mathrm{C}$. Because we focus on the northern abyssal ocean whose ventilation 502 timescales typically exceed centuries, the influence of bomb ${ }^{14} \mathrm{C}$ should not significantly affect the qualitative structure discussed here ${ }^{61}$. In particular, the surfaces of meridional flow reversal

504 identified in radiocarbon distributions are corroborated by other hydrographic fields such as stratification, oxygen or silicic acid (see Extended Data Fig. 7). In contrast, these features are

506 blurred in the bomb-corrected GLODAP climatology product ${ }^{70}$, whose accuracy may be reduced in the abyss ${ }^{66}$. The neutrally-averaged radiocarbon climatology constructed for the present study

508 is available for download at https://www.nodc.noaa.gov/ocads/oceans/DC14_climate.html.

Pacific ocean abyssal pathways. The density profile of summed incrop areas over the Pacific 510 exhibits two different peaks (Extended Data Fig. 9a,d): a dominant peak at $\gamma=28.11 \mathrm{~kg} \mathrm{~m}^{-3}$ and a secondary peak at $\gamma=28.03 \mathrm{~kg} \mathrm{~m}^{-3}$. The latter peak originates from the subbasins situated east of

512 the East Pacific Rise (Extended Data Fig. 1). These subbasins receive an inflow of Circumpolar Deep Water ${ }^{71,72}$, which is older than the AABW entering the southwestern Pacific but younger

514 than southward-flowing deep waters (Extended Data Fig. 2c,f). Given that abyssal upwelling in the Pacific is inferred to be mostly confined to below the crest of the East Pacific Rise, we posit 516 that all or part of the Circumpolar Deep Water inflow feeds a secondary overturning cell restricted to the southeastern Pacific and the $28-28.06 \mathrm{~kg} \mathrm{~m}^{-3}$ density range (Extended Data Fig. 2).

518 North of $32^{\circ} \mathrm{S}$ this overturning cell is presumed to be separate from the main Pacific abyssal cell fed by AABW.

520 Our analysis suggests that the bulk of the Pacific AABW waters returns to $32^{\circ} \mathrm{S}$ deeper than 2.5 $\mathrm{km}$. This result accords with early analyses of transport across zonal hydrographic sections of the

522 North Pacific ${ }^{73-75}$ and the South Pacific ${ }^{71,76}$ but contrasts with more recent inverse estimates of overturning transports at $32^{\circ} \mathrm{S}^{10,72,77-81}$. Although the latter estimates all imply a shallower return

524 flow at this latitude, they exhibit significant spread, most place the meridional flow reversal well above the $28.11 \mathrm{~kg} \mathrm{~m}^{-3}$ density surface, and many conflict with a high-resolution inverse study of

526 the eastern South Pacific circulation ${ }^{82}$. The uncertainties carried by the inverse solutions at this location thus appear too large to permit validation or invalidation of the present results. Further

528 work is required to reconcile herein proposed regime transitions with large-scale property budgets and to narrow down ranges for the strength and structure of the deep southward return 530 flow.

Indian ocean abyssal pathways. Extended Data Fig. 3 documents the relationships between the 532 distributions of seafloor areas, incrop areas and radiocarbon content in the Indian basin. The latter hosts multiple subbasins with different ventilation histories. For improved interpretation,

534 subbasins with overlapping latitude ranges are therefore shown in separate panels. Two separate AABW routes ventilate the abyssal Indian ocean ${ }^{83}$ (Extended Data Fig. 1): an east-route through

536 the Perth, Wharton and Cocos basins, with some connection to the Central Indian basin (Extended Data Fig. 3a-f); and a west-route through the Madagascar, Mascarene and Somali 538 basins, and into the Arabian basin (Extended Data Fig. 3g-1).

Inflow of young, dense AABW in the eastern Indian ocean is clearly seen in its radiocarbon distribution. Yet an unambiguous ${ }^{14} \mathrm{C}$-signature of the level of meridional flow reversal at $32^{\circ} \mathrm{S}$ is 
not distinguishable, in part due to the small ventilated volume of the subbasin. Indeed, a distinct transition towards much older waters near $3.7 \mathrm{~km}$ depth, approximately coinciding with the weak incrop level (the inferred diabatic-adiabatic transition), suggests that the seafloor distribution 544 constrains the upwelling and southward return of young Antarctic-sourced waters to depths greater than $3.7 \mathrm{~km}$. Such a compressed AABW overturning in the eastern Indian ocean is 546 consistent with: (i) weak AABW throughflow to the Central Indian basin, whose abyssal radiocarbon activities are much lower than those of eastern Indian bottom waters; (ii) the steep 548 topographic barriers bounding the subbasin, which limit dianeutral upwelling; (iii) the location of the silicic acid maximum within the northern half of the subbasin, above that overturning

550 (Extended Data Fig. 7f). Additional deep water overturning in the 28.1-28.17 $\mathrm{kg} \mathrm{m}^{-3}$ density range driven by water mass transformation in the Central Indian basin is expected to be weak due to the

552 low mixing rates ${ }^{85,33}$ and low radiocarbon concentrations observed north of $30^{\circ} \mathrm{S}$ in this density range (Extended Data Fig. 3i,l). We thus interpret the apparent $\mathrm{Si}(\mathrm{OH})_{4}$ tongue near $28.12 \mathrm{~kg} \mathrm{~m}^{-3}$

554 north of $15^{\circ} \mathrm{S}$ (Extended Data Fig. 7f) as due to local production, diffusion and/or horizontal recirculation, rather than net meridional flow ${ }^{84}$.

556 The western Indian ocean has a more gradual decrease of its area, due to the presence of weaklysloping ridges. As a result, significant seafloor and incrop areas extend higher up in the water 558 column, to about $2.5 \mathrm{~km}$ depth. The predicted northward-southward and diabatic-adiabatic transitions lie near $4 \mathrm{~km}\left(28.13 \mathrm{~kg} \mathrm{~m}^{-3}\right)$ and $2.7 \mathrm{~km}\left(28.04 \mathrm{~kg} \mathrm{~m}^{-3}\right)$ depth, respectively. These 560 compare well with the observed $\Delta^{14} \mathrm{C}$ and $\mathrm{Si}(\mathrm{OH})_{4}$ distributions (Extended Data Figs. 3c and $7 \mathrm{c}$ ). Nonetheless, sampling limitations (Extended Data Fig. 8b), lateral redistribution by mixing along 562 density surfaces, and the inflow of relatively young waters of North Atlantic origin into deep layers of the basin ${ }^{5}$ hinder clearer identification of the overturning structure in the radiocarbon 564 data. The Arabian basin has no water denser than $28.13 \mathrm{~kg} \mathrm{~m}^{-3}$, so that its contribution to the overturning appears restricted to the transformation of lighter deep waters.

566 The inferred structure of the deep Indian ocean overturning contrasts with results of steady geostrophic box inversions ${ }^{10,77,79,81,86-89}$, which suggest a shallower return of dense southern waters.

568 However, published inverse estimates of the Indian overturning differ widely in structure and strength ${ }^{85}$. Complexity of the flow and topography of the basin likely plays a role in this

570 scatter $^{80,87,89}$. In particular, the limited number of abyssal density layers considered in the inverse box models disallows resolution of the compressed AABW overturning identified in the eastern

572 Indian ocean: most inversions carry one layer denser than $28.15 \mathrm{~kg} \mathrm{~m}^{-3}$ in this subbasin, and predict either net northward ${ }^{81}$ or southward ${ }^{89}$ flow in the layer at $32^{\circ} \mathrm{S}$. Further, the presence of

574 multiple peaks in the total incrop area profile of the Indian ocean (Extended Data Fig. 9c,f), related to its topographic partitioning, suggests that the basin's overturning streamfunction may

576 exhibit several abyssal peaks. Coexistence of several abyssal overturning cells traversing relatively small depth, density and other property contrasts could possibly explain the limited

578 consistency of hydrographic inversions and their mismatch with water mass transformation estimates $^{85,90}$.

580 Atlantic ocean abyssal pathways. Antarctic Bottom Water (AABW) enters the Atlantic ocean west of the Mid-Atlantic Ridge ${ }^{83}$ (Extended Data Figs. 1 and 4a-c). As opposed to the situation in

582 the Pacific ocean, it carries a low radiocarbon signature relative to the overlying ${ }^{14} \mathrm{C}$-rich North Atlantic Deep Water (NADW). At $32^{\circ} \mathrm{S}$, the boundary between northward-flowing AABW and 584 southward-flowing NADW coincides with the strongest vertical $\Delta{ }^{14} \mathrm{C}$ gradient, observed at $\gamma=$ 
$28.14 \mathrm{~kg} \mathrm{~m}^{-3}$. This density surface is also the peak incrop surface across the western Atlantic, consistent with control by incrop areas of the level of meridional flow reversal. Transport analyses ${ }^{9,10}$ and the climatological density field further indicate weak southward influx of waters 588 denser than $28.14 \mathrm{~kg} \mathrm{~m}^{-3}$ at $48^{\circ} \mathrm{N}$, substantiating a match between the levels of meridional flow reversal, peak incrop area and maximum dianeutral upwelling. We infer that the pivotal 590 upwelling across the $28.14 \mathrm{~kg} \mathrm{~m}^{-3}$ surface occurs mainly between $30^{\circ} \mathrm{N}$ and $45^{\circ} \mathrm{N}$ near $4.5 \mathrm{~km}$ depth, where the weak abyssal stratification and large seafloor availability combine to maximize

592 incrops (Extended Data Fig. 4b). Additionally, weak seafloor and incrop areas shallower than 3 $\mathrm{km}$ imply that the dianeutral upwelling of bottom waters and their southward return are 594 concentrated at depths greater than $3 \mathrm{~km}$.

The abyssal eastern Atlantic (Extended Data Fig. 4d-f) is primarily fed from its western counterpart through the Chain $\left(1^{\circ} \mathrm{S}\right)$, Romanche $\left(1^{\circ} \mathrm{N}\right)$ and Vema $\left(11^{\circ} \mathrm{N}\right)$ fracture zones, with additional NADW inflow from the northern end of the basin ${ }^{83,91}$ (Extended Data Fig. 1). The $\Delta^{14} \mathrm{C}$

598 levels at the outflow of the three fracture zones approach $-115 \%$, which is closer to western Atlantic NADW levels $(\sim-100 \%)$ than AABW levels $(\sim-150 \%)$. This suggests that the 600 outflows are dominated by NADW, not AABW, in accord with local observational surveys ${ }^{92-95,28}$ and silicic acid distributions (Extended Data Fig. 7g,h). Consequently, the eastern Atlantic

602 contributes primarily to the transformation and upwelling of NADW. Because the estimated AABW throughflow to the eastern basins ${ }^{94,95}$ is only a fraction of the $32^{\circ} \mathrm{S}$ Atlantic AABW 604 input $^{96,27}$, we conclude that dianeutral upwelling within the western Atlantic controls the presentday boundary between northward-flowing AABW and southward-flowing NADW. The seafloor 606 and tracer distributions of the eastern Atlantic nonetheless indicate that, there as in the western Atlantic, dianeutral upwelling and AABW influence are most significant below the $3 \mathrm{~km}$ 608 geopotential.

Radiocarbon evidence from the Atlantic and Indian basins thus bears out the relationship between the abyssal overturning structure and the depth and density distributions of the ocean floor. Major topographic obstacles and constrictions at subbasin boundaries either (i) catalyse the 612 transformation of AABW or (ii) restrict its access to certain subbasins, but do not override this relationship. In situation (i), flow constrictions contribute to the creation of a more homogeneous

614 bottom water mass, focusing incrop areas into a narrow density range and favouring rapid upwelling at the peak incrop layer downstream. Such inter-basin passages lie below the boundary

616 between northward AABW transport and southward deep water transport. In situation (ii), topographic barriers limit the role of more isolated subbasins in the transformation and upwelling

618 of lighter deep waters. The additional deep boundary transformation occurring en route to and within these subbasins (namely the eastern Atlantic, the Arabian basin and the Central Indian

620 basin) concerns mostly waters lighter than AABW and denser than $28.05 \mathrm{~kg} \mathrm{~m}^{-3}$ (Extended Data Fig. 9).

622 Code availability. Code for the generation and usage of the distance look-up table is available at http://www.marine.csiro.au/ dunn/cars2009/DLU/. Analysis scripts are available from 624 casimir.delavergne@gmail.com on request.

Data availability. The global bathymetry product can be downloaded at 626 https://www.ngdc.noaa.gov/mgg/global/etopo2.html. The WOCE hydrographic climatology is available at http://icdc.cen.uni-hamburg.de/1/daten/ocean/woce-climatology.html. GLODAPv2 radiocarbon data can be retrieved from https://www.nodc.noaa.gov/ocads/data/0162565.xml. The 
constructed radiocarbon climatology is made available by the authors at 630 https://www.nodc.noaa.gov/ocads/oceans/DC14_climate.html.

\section{Methods references}

50. Garrett, C. \& St. Laurent, L. C. Aspects of deep ocean mixing. J. Oceanogr. 58, 11-24 (2002).

634 51. Molemaker, M. J., McWilliams, J. C. \& Dewar, W. K. Submesoscale instability and generation of mesoscale anticyclones near a separation of the California Undercurrent. J. Phys.

636 Oceanogr. 45, 613-629 (2015).

52. Gula, J., Molemaker, M. J. \& McWilliams, J. C. Topographic generation of submesoscale centrifugal instability and energy dissipation. Nat. Commun. 7, 12,811 (2016).

53. Jayne, S. R. \& St. Laurent, L. C. Parameterizing tidal dissipation over rough topography. Geophys. Res. Lett. 28, 811-814 (2001).

54. Nikurashin, M. \& Ferrari, R. Radiation and dissipation of internal waves generated by

642 geostrophic motions impinging on small-scale topography: theory. J. Phys. Oceanogr. 40, 1,0551,074 (2010).

644 55. Muller, C. J. \& Bülher, O. Saturation of the internal tides and induced mixing in the abyssal ocean. J. Phys. Oceanogr. 39, 2,077-2,096 (2009).

646 56. Nikurashin, M. \& Legg, S. A mechanism for local dissipation of internal tides generated at rough topography. J. Phys. Oceanogr. 41, 378-395 (2011).

648 57. Bülher, O. \& Holmes-Cerfon, M. Decay of an internal tide due to random topography in the ocean. J. Fluid. Mech. 678, 271-293 (2011).

650 58. Goff, J. A. Global prediction of abyssal hill root-mean-square heights from small-scale altimetric gravity variability. J. Geophys. Res. 115, B12104 (2010).

652 59. Nycander, J. Generation of internal waves in the deep ocean by tides. J. Geophys. Res. 110, C10028 (2005).

654 60. Melet, A. et al. Internal tide generation by abyssal hills using analytical theory. J. Geophys. Res. 118, 6,303-6,318 (2013).

656 61. Nikurashin, M., Ferrari, R., Grisouard, N. \& Polzin, K. The impact of finite-amplitude bottom topography on internal wave generation in the Southern Ocean. J. Phys. Oceanogr. 44, 2,9386582,950 (2014).

62. Stuiver, M. \& Polach, H. A. Reporting of ${ }^{14} \mathrm{C}$ data. Radiocarbon 19, 355-363 (1977).

660 63. Stuiver, M., Quay, P. D. \& Ostlund, H. G. Abyssal water carbon-14 distribution and the age of the world oceans. Science 219, 849-851 (1983). 

and diapycnic mixing in determining the radiocarbon distribution in the Pacific. J. Geophys. Res. 109, C06015 (2004).

65. Holzer, M. \& Primeau, F. W. The path-density distribution of oceanic surface-to-surface transport. J. Geophys. Res. 113, C01018 (2008).

66. Burke, A. et al. The glacial mid-depth radiocarbon bulge and its implications for the overturning circulation. Paleoceanography 30, 1,021-1,039 (2015).

67. Ridgway, K. R., Dunn, J. R. \& Wilkin, J. L. Ocean interpolation by four-dimensional weighted least squares - application to waters around Australasia. J. Atmos. Oceanic Technol. 19, 1,357-1,375 (2002).

672 68. Dunn, J. R. \& Ridgway, K. R. Mapping ocean properties in regions of complex topography. Deep-Sea Res. 49, 591-604 (2002).

674 69. Stuiver, M., Robinson, S. W., Ostlund, H. G. \& Dorsey, H. G. Carbon-14 calibration between the University of Washington and the University of Miami Geosecs laboratories. Earth Planet. 676 Sci. Lett. 23, 65-68 (1974).

70. Key, R. M. et al. A global ocean carbon climatology: results from Global Data Analysis 678 Project (GLODAP). Glob. Biogeochem. Cycles 18, GB4031 (2004).

71. Warren, B. A. Transpacific hydrographic sections at Lats. $43^{\circ} \mathrm{S}$ and $28^{\circ} \mathrm{S}$ : the SCORPIO expedition - II. Deep water. Deep-Sea Res. 20, 9-38 (1973).

72. Wijffels, S. E., Toole, J. M. \& Davis, R. Revisiting the South Pacific subtropical circulation: 682 a synthesis of World Ocean Circulation Experiment observations along $32^{\circ} \mathrm{S}$. J. Geophys. Res. 106, 19,481-19,513 (2001).

684 73. Roemmich, D. \& McCallister, T. Large scale circulation of the North Pacific ocean. Progr. Oceanogr. 22, 171-204 (1989).

686 74. Bryden, H. L., Roemmich, D. H. \& Church, J. A. Ocean heat transport across $24^{\circ} \mathrm{N}$ in the Pacific. Deep-Sea Res. 38, 297-324 (1991).

688 75. Wijffels, S. E. et al. The water masses and circulation at $10^{\circ} \mathrm{N}$ in the Pacific. Deep-Sea Res. 43, 501-504 (1996).

690 76. Wunsch, C., Hu, D. \& Grant, R. Mass, heat, salt and nutrient fluxes in the South Pacific Ocean. J. Phys. Oceanogr. 13, 725-753 (1983).

692 77. Sloyan, B. \& Rintoul, S. R. The Southern Ocean limb of the global deep overturning circulation. J. Phys. Oceanogr. 31, 143-173 (2001).

694 78. Macdonald, A. M. et al. The WOCE-era 3-D Pacific ocean circulation and heat budget. Progr. Oceanogr. 82, 281-325 (2009).

696 79. Katsumata, K., Sloyan, B. \& Masuda, S. Diapycnal and isopycnal transports in the Southern Ocean estimated by a box inverse model. J. Phys. Oceanogr. 43, 2,270-2,287 (2013). 
698 80. Naveira Garabato, A. C., Williams, A. P. \& Bacon, S. The three-dimensional overturning circulation of the Southern Ocean during the WOCE era. Progr. Oceanogr. 120, 41-78 (2014).

700 81. Hernandez-Guerra, A. \& Talley, L. D. Meridional overturning transports at $30^{\circ} \mathrm{S}$ in the Indian and Pacific oceans in 2002-2003 and 2009. Progr. Oceanogr. 146, 89-120 (2016).

702 82. Faure, V. \& Speer, K. Deep circulation in the eastern South Pacific ocean. J. Mar. Res. 70, 748-778 (2012).

704 83. Mantyla, A. W. \& Reid, J. L. Abyssal characteristics of the World Ocean waters. Deep-Sea Res. 30, 805-833 (1983).

706 84. Hogg, N. G. A least-squares fit of the advective-diffusive equations to Levitus atlas data. $J$. Mar. Res. 45, 347-375 (1987).

708 85. Huussen, T. N., Naveira Garabato, A. C., Bryden, H. L. \& McDonagh, E. L. Is the deep Indian ocean MOC sustained by breaking internal waves? J. Geophys. Res. 117, C08024 (2012).

710 86. Robbins, P. E. \& Toole, J. M. The dissolved silica budget as a constraint on the meridional overturning circulation of the Indian Ocean. Deep-Sea Res. 44, 879-906 (1997).

712 87. Ganachaud, A., Wunsch, C., Marotzke, J. \& Toole, J. M. Meridional overturning and largescale circulation of the Indian Ocean. J. Geophys. Res. 105, 26,117-26,134 (2000).

714 88. Bryden, H. L. \& Beal, L. M. Role of the Agulhas Current in Indian Ocean circulation and associated heat and freshwater fluxes. Deep-Sea Res. 48, 1,821-1,845 (2001).

716 89. McDonagh, E. L., Bryden, H. L., King, B. A. \& Sanders, R. J. The circulation of the Indian Ocean at $32^{\circ}$ S. Progr. Oceanogr. 79, 20-36 (2008).

718 90. de Lavergne, C., Madec, G., Le Sommer, J., Nurser, A. J. G. \& Naveira Garabato, A. C. The impact of a variable mixing efficiency on the abyssal overturning. J. Phys. Oceanogr. 46, 663$720681(2016)$.

91. Mercier, H., Speer, K. G. \& Honnorez, J. A. Flow pathways of bottom water through the 722 Romanche and Chain fracture zones. Deep-Sea Res. 41, 1,457-1,477 (1994).

92. Friedrichs, M. A. M., McCartney, M. S. \& Hall, M. M. Hemispheric asymmetry of deep 724 water transport modes in the western Atlantic. J. Geophys. Res. 99, 25,165-25,179 (1994).

93. Fischer, J., Rhein, M., Schott, F. \& Stramma, L. Deep water masses and transports in the 726 Vema fracture zone. Deep-Sea Res. 43, 1,067-1,074 (1996).

94. Mercier, H. \& Speer, K. G. Transport of bottom water in the Romanche fracture zone and the 728 Chain fracture zone. J. Phys. Oceanogr. 28, 779-790 (1998).

95. Demidov, A. N., Dobrolyubov, S. A., Morozov, E. G. \& Tarakanov, R. Y. Transport of 730 bottom waters through the Vema fracture zone in the Mid-Atlantic Ridge. Dokl. Earth Sci. 416, $1,120-1,124$ (2007). 


\section{Extended data legends}

736 Extended Data Figure 1: Bottom density contrasts and basin masks. a, Shaded bottom neutral density field, with the $4 \mathrm{~km}$ bathymetric contour overlaid in black. b, Basin masks

738 employed for Extended Data Figs. 2-4. The dianeutral circulation, which is essentially confined to the near-bottom, can largely be tracked from the bottom density distribution. The four main 740 northward paths of AABW are identified in the western Indian, eastern Indian, western Pacific and western Atlantic oceans. The southeastern Pacific, east of the East Pacific Rise, hosts inflow 742 of Circumpolar Deep Water ${ }^{71,72}$ (see Extended Data Fig. 2). Large bottom density differences across connected, AABW-ventilated subbasins largely reflect the efficient consumption of the

744 densest through- and over-flowing waters at deep straits and sills. The Chain (CFZ), Romanche (RFZ) and Vema (VFZ) fracture zones linking the abyssal eastern and western Atlantic are 746 indicated.

Extended Data Figure 2: Seafloor and radiocarbon distributions of the full Pacific and the

748 southeastern Pacific. The full Pacific (shown in a-c) comprises the main Pacific (shown in Fig. 3 ) and the southeastern Pacific (shown in d-f) domains defined in Extended Data Fig. 1b. a,d,

750 Zonally-summed seafloor areas as a function of latitude and depth. b,e, Zonally-summed incrop areas as a function of latitude and pseudo-depth. c,f, Along-density zonal mean radiocarbon

752 content $\left(\Delta{ }^{14} \mathrm{C}\right)$ as a function of latitude and pseudo-depth. White curves depict the local northward-southward and diabatic-adiabatic transition levels inferred from the incrop area

754 distribution, as in Fig. 3. The cluster of large incrop areas within $28-28.06 \mathrm{~kg} \mathrm{~m}^{-3}$ south of $20^{\circ} \mathrm{N}$ seen in $\mathbf{b}$ originates in the southeastern Pacific, which hosts a secondary circulation branch ${ }^{71,72}$

756 separate from the main abyssal overturning cell (Methods).

Extended Data Figure 3: Indian seafloor and radiocarbon distributions. a,d,g,j, Zonallysummed seafloor areas as a function of latitude and depth. b,e,h,, $\mathbf{k}$, Zonally-summed incrop areas as a function of latitude and pseudo-depth. c,f,i,l, Along-density zonal mean radiocarbon content

$760\left(\Delta^{14} \mathrm{C}\right)$ as a function of latitude and pseudo-depth. Notice the different colorscales from Fig. 3. White curves depict the local northward-southward and diabatic-adiabatic transition levels

762 inferred from the incrop area distribution, as in Fig. 3. In the (g-i) Central Indian Basin, whose abyss is not fed from the south but instead through gaps in the Ninety East Ridge, white curves

764 correspond to the peak and weak incrop density surfaces based on the total subbasin incrop profile. Subbasin masks are shown in Extended Data Fig. 1b.

766 Extended Data Figure 4: Atlantic seafloor and radiocarbon distributions. a,d, Zonallysummed seafloor areas as a function of latitude and depth. b,e, Zonally-summed incrop areas as a

768 function of latitude and pseudo-depth. c,f, Along-density zonal mean radiocarbon content $\left(\Delta^{14} \mathrm{C}\right)$ as a function of latitude and pseudo-depth. Notice the different colorscales from Fig. 3. In the (a-

770 c) western Atlantic, white curves depict the local northward-southward and diabatic-adiabatic transition levels inferred from the incrop area distribution, as in Fig. 3. In the (d-f) eastern

772 Atlantic, whose abyss is not fed from the south but instead through ridge gaps in the vicinity of 
the equator, white curves correspond to peak and weak incrop density surfaces based on the total subbasin incrop profile. Subbasin masks are shown in Extended Data Fig. 1b.

Extended Data Figure 5: Simplified sketch of the density transformation associated with equivalently, of a mixing-driven density flux that is uniform in the interior. Density loss occurs in a thin bottom boundary layer. The net density loss within a density layer, and therefore the dianeutral transport across it, is proportional to the layer's incrop area. b. Scenario (s2): case of bottom-enhanced turbulence where density loss in a thin bottom layer is compensated by an equal and opposite density gain above that layer. Density loss and density gain layers are sketched with equal thicknesses to illustrate this compensation: a density layer undergoes net density loss if the red area dominates over the blue area, and conversely. As an approximate rule, a density layer loses density in proportion to its incrop area but gains density in proportion to the incrop area of its underlying neighbour. Consequently, the larger the increase (decrease) of incrop area with height, the larger the net density loss (gain) of a density layer, and therefore the larger the net upwelling (downwelling) transport across it.

788 Extended Data Figure 6: Bottom-intensified mixing scenarios. $32^{\circ} \mathrm{S}-48^{\circ} \mathrm{N}$ density profiles of $(\mathbf{a}, \mathbf{d})$ the total density flux, (b,e) the density flux averaged over density surfaces and (c,f) total

790 dianeutral transports, under various scenarios for the local intensity of bottom-intensified mixing. Specifically, we set the magnitude of local density-flux profiles proportional to (see also labels and Methods): (a-c, orange and red) characteristics of the large-scale topography; (a-c, dark and pale blue) characteristics of small-scale abyssal hills; (d-f, orange and red) bottom energy fluxes

794 into internal waves; (d-f, dark and pale blue) powers of the bottom buoyancy frequency. Absolute values of density fluxes are chosen such that the peak upwelling rate is $25 \times 10^{6} \mathrm{~m}^{3} \mathrm{~s}^{-1}$ under all

796 scenarios. Only the structure - as opposed to the magnitude - of dianeutral transports thus warrants interpretation.

798 Extended Data Figure 7: Silicic acid distributions. Along-density zonal mean silicic acid concentration $^{41}$ in the (a) main Pacific, (b) southeastern Pacific, (c) western Indian, (d) Arabian,

800 (e) central Indian, (f) eastern Indian, (g) western Atlantic and (h) eastern Atlantic domains. Domains are defined in Extended Data Fig. $1 \mathrm{~b}$.

802 Extended Data Figure 8: Example radiocarbon map and underlying data. $\Delta^{14} \mathrm{C}(\mathrm{a})$ mapped and (b) measured on the $28.045 \mathrm{~kg} \mathrm{~m}^{-3}$ neutral density surface. Dark grey patches in a are

804 portions of the density surface that are unmapped due to insufficient data density. Similar maps have been constructed for 140 density surfaces spanning the world ocean's neutral density range ${ }^{13}$.

806 Extended Data Figure 9: Subbasin profiles of incrop area. Total incrop area as a function of (a-c) density and (d-f) pseudo-depth at $32^{\circ} \mathrm{S}$, shown for labelled subdomains of the (a,d) Pacific,

808 (b,e) Atlantic and (c,f) Indian oceans. The abyssal Arabian and central Indian subbasins exchange with the Southern Ocean via the western and eastern Indian oceans, respectively. We therefore 810 use the $32^{\circ} \mathrm{S}$ pseudo-depth of the western and eastern Indian oceans for the (orange) Arabian and (pale blue) central Indian profiles in $\mathbf{f}$, respectively. Subbasin masks are shown in Extended Data 812 Fig. 1b. 
Figure 1
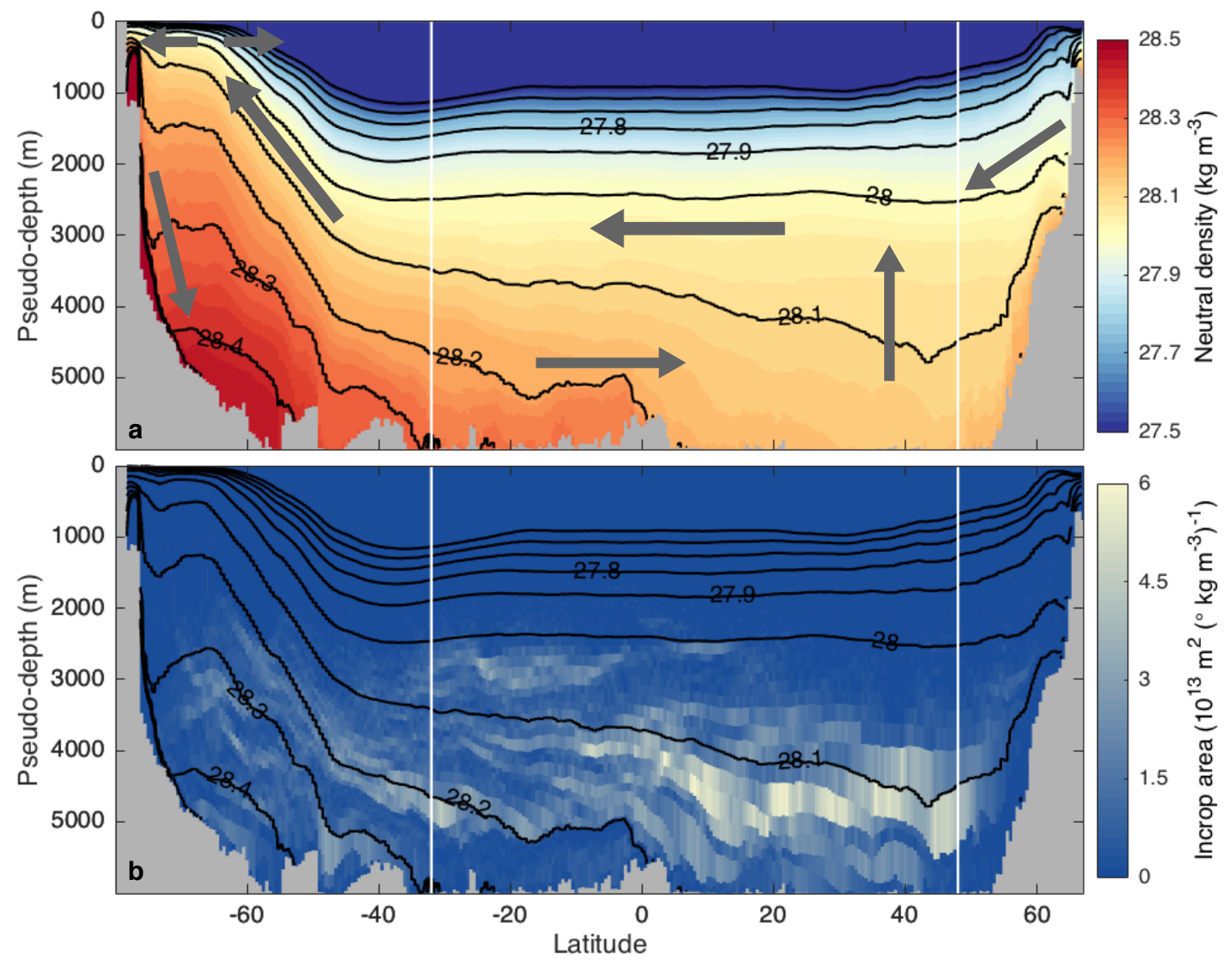
Figure 2
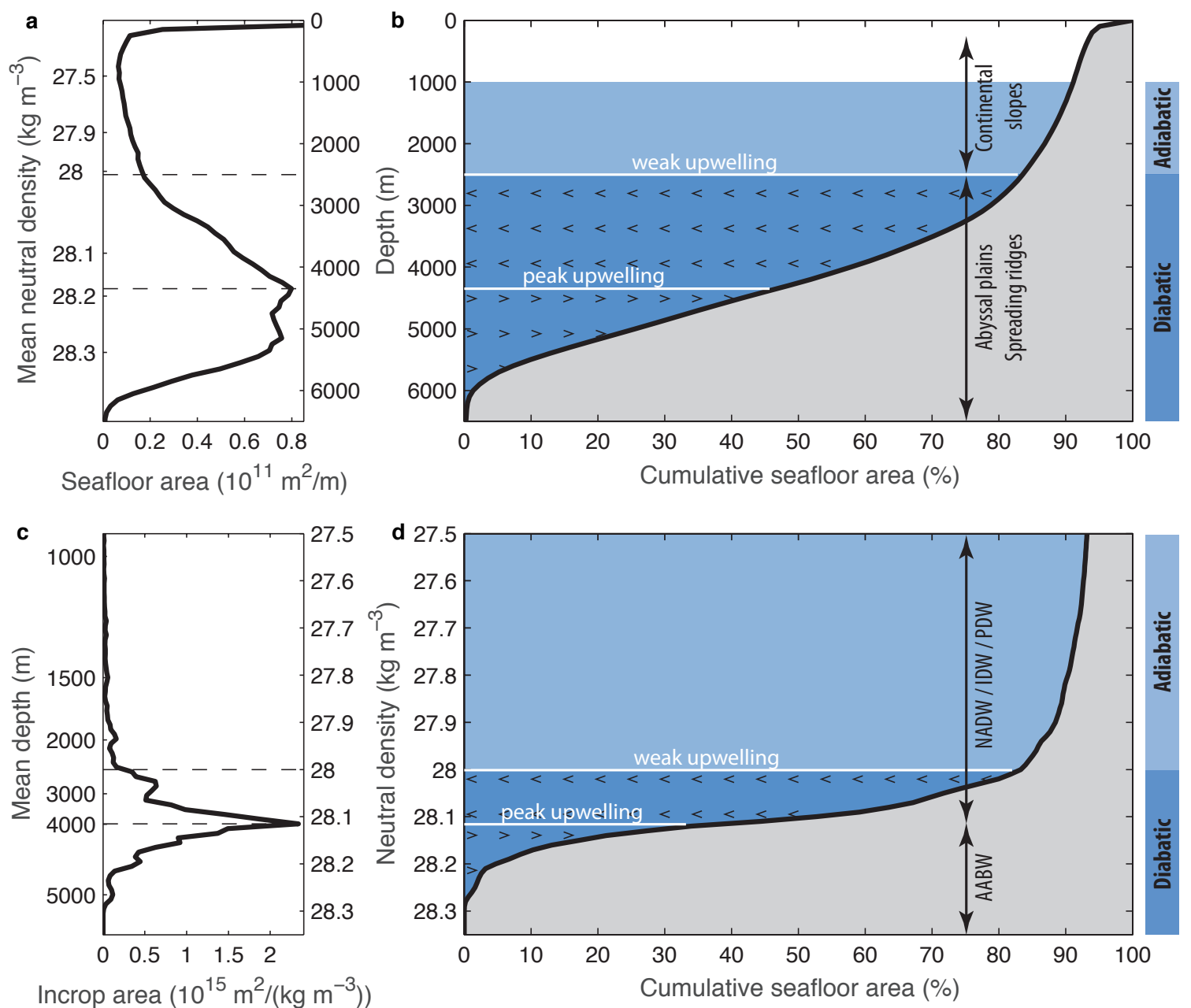

Incrop area $\left(10^{15} \mathrm{~m}^{2} /\left(\mathrm{kg} \mathrm{m}^{-3}\right)\right)$ 
Figure 3
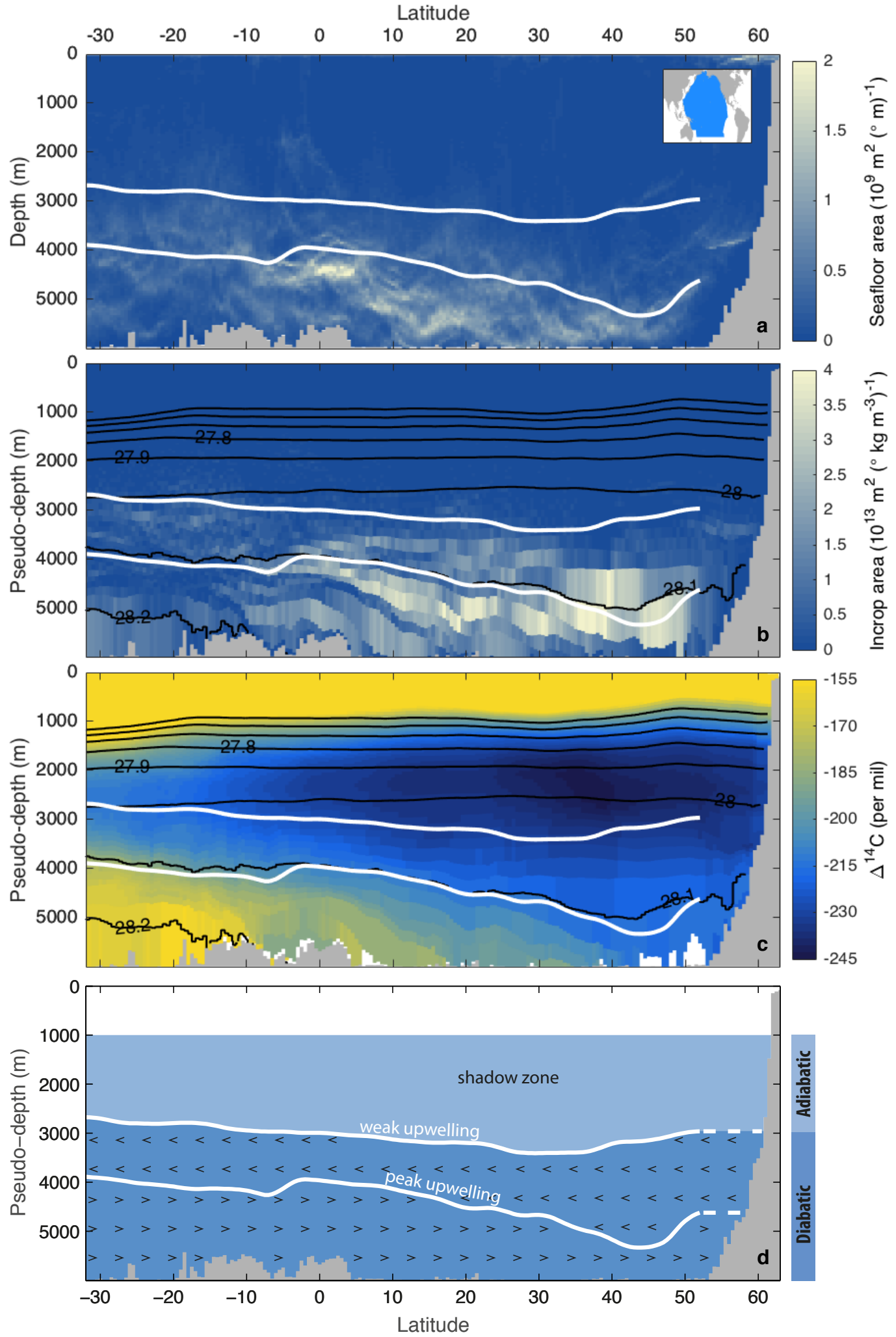
Figure 4

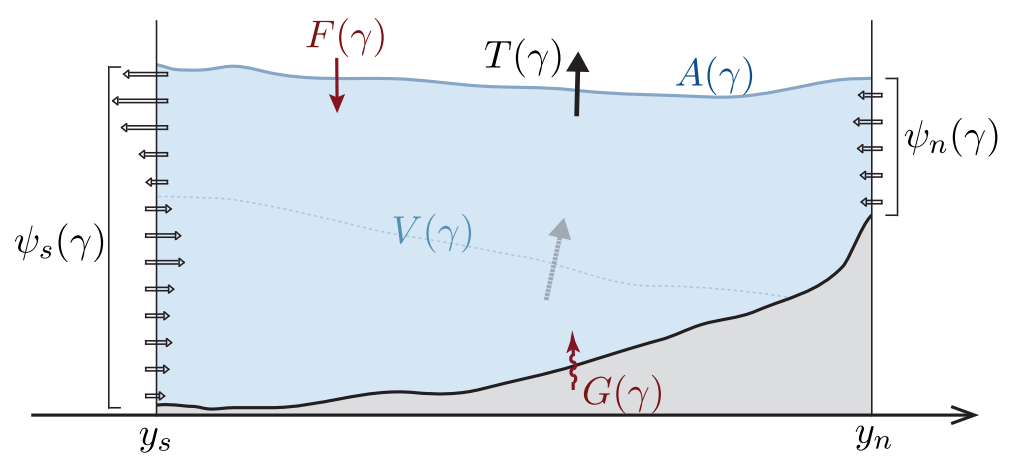


Figure 5

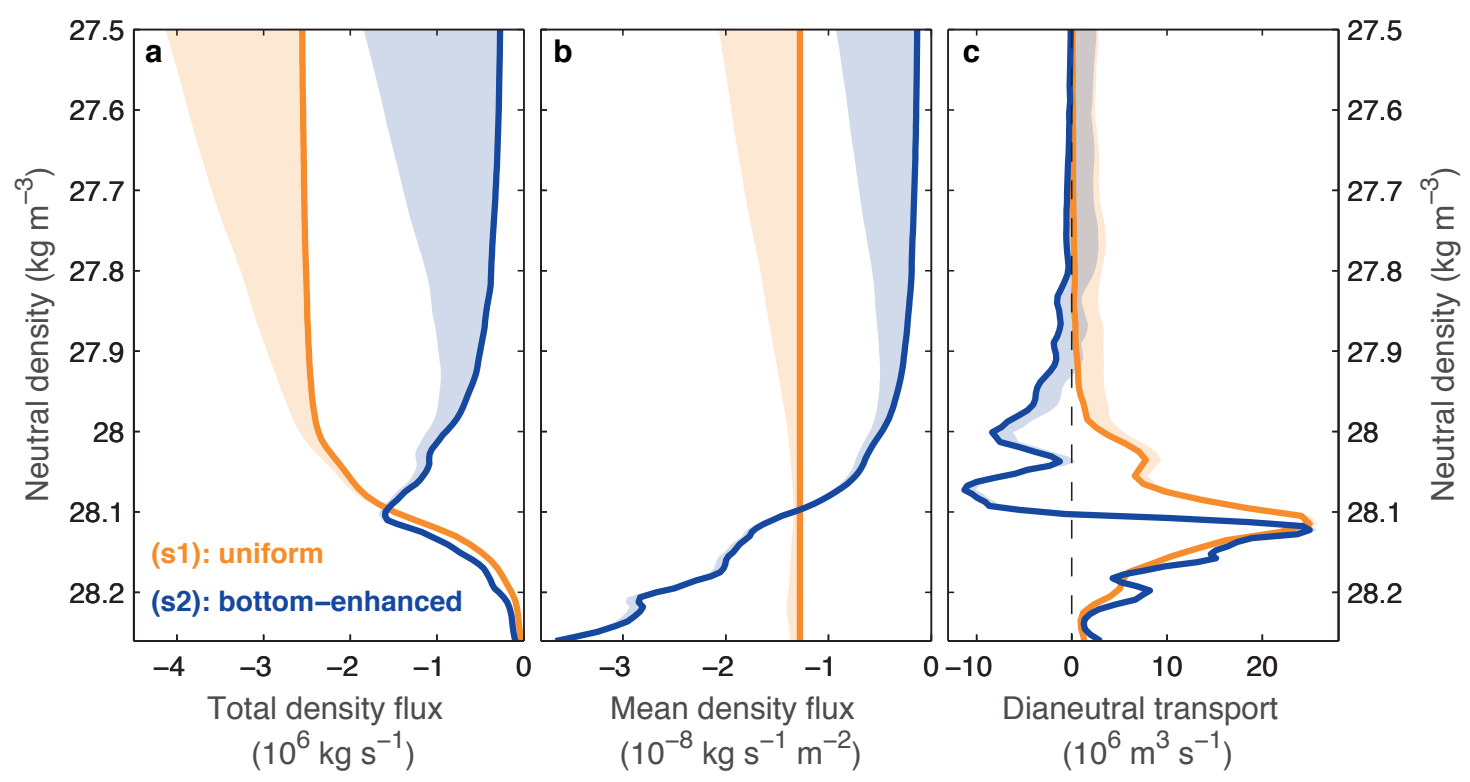




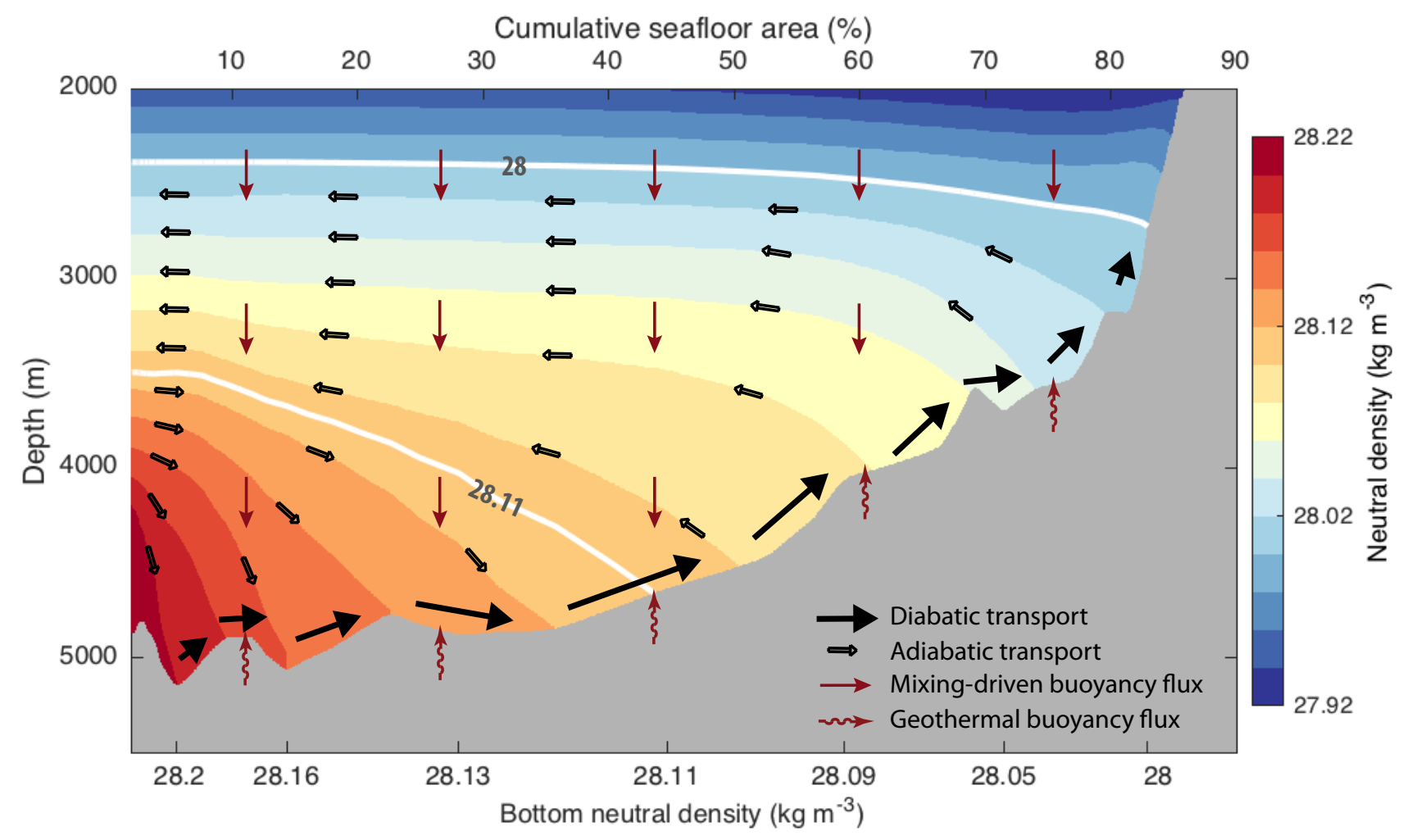


ED Figure 1

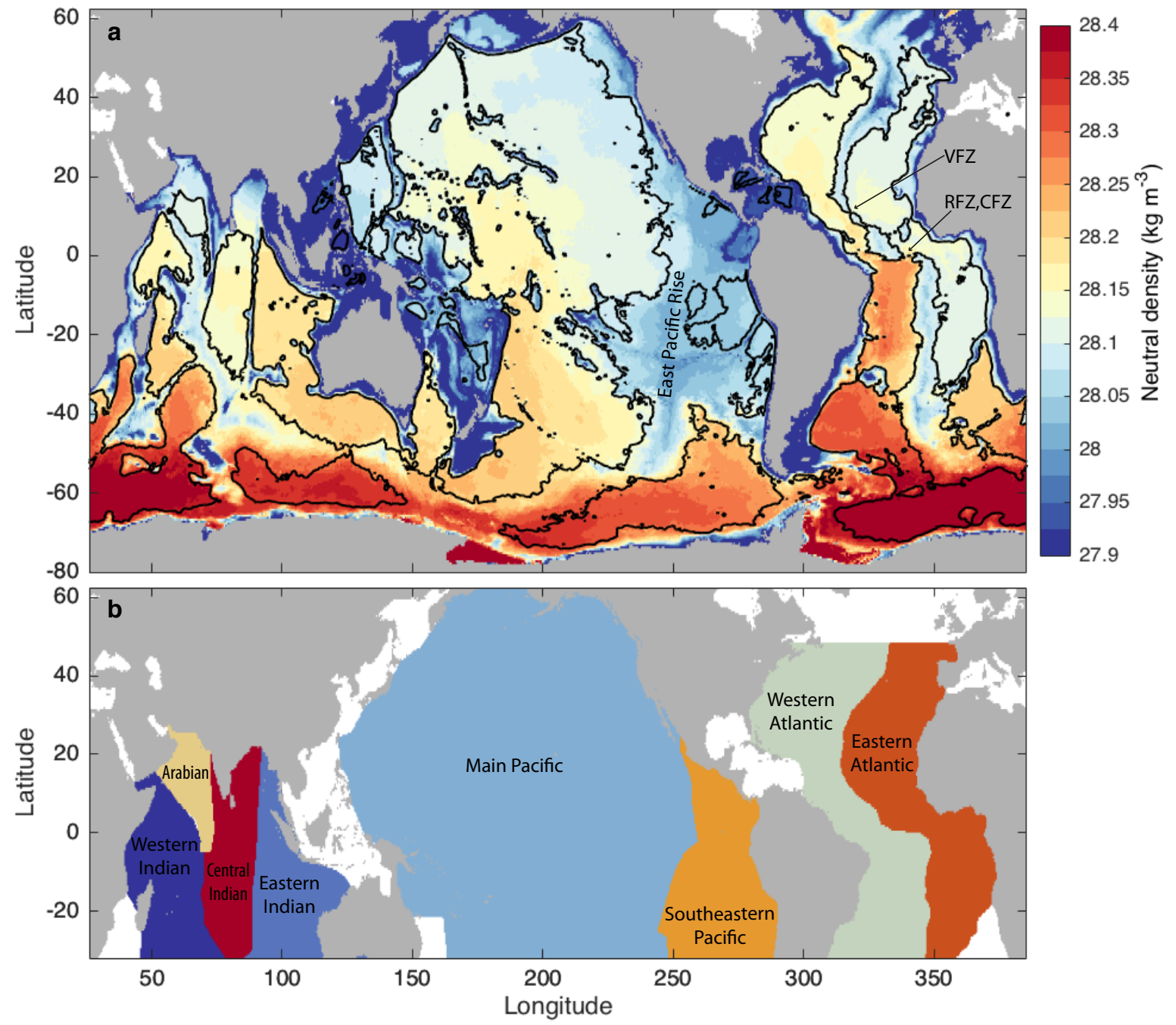




\section{ED Figure 2}
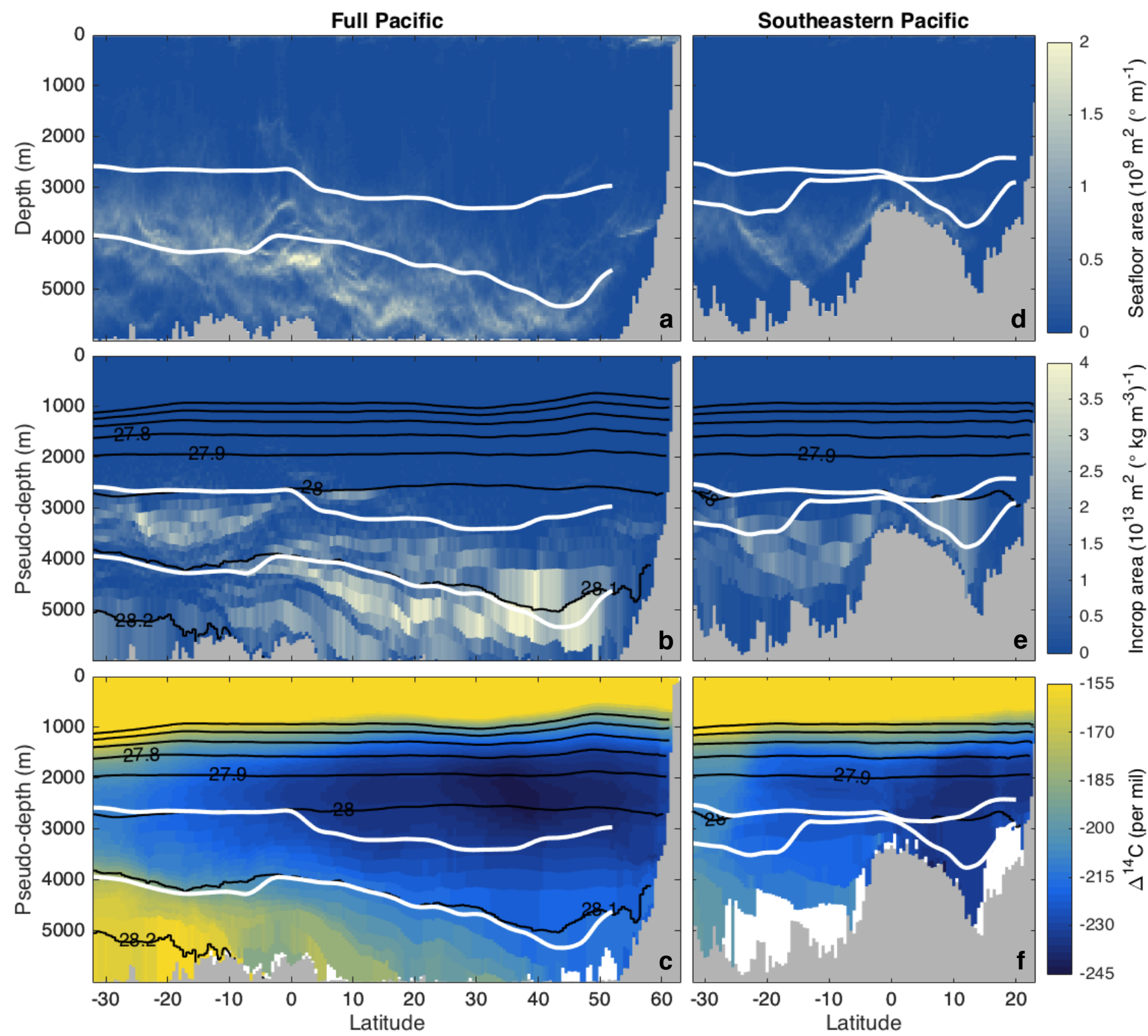


\section{ED Figure 3}
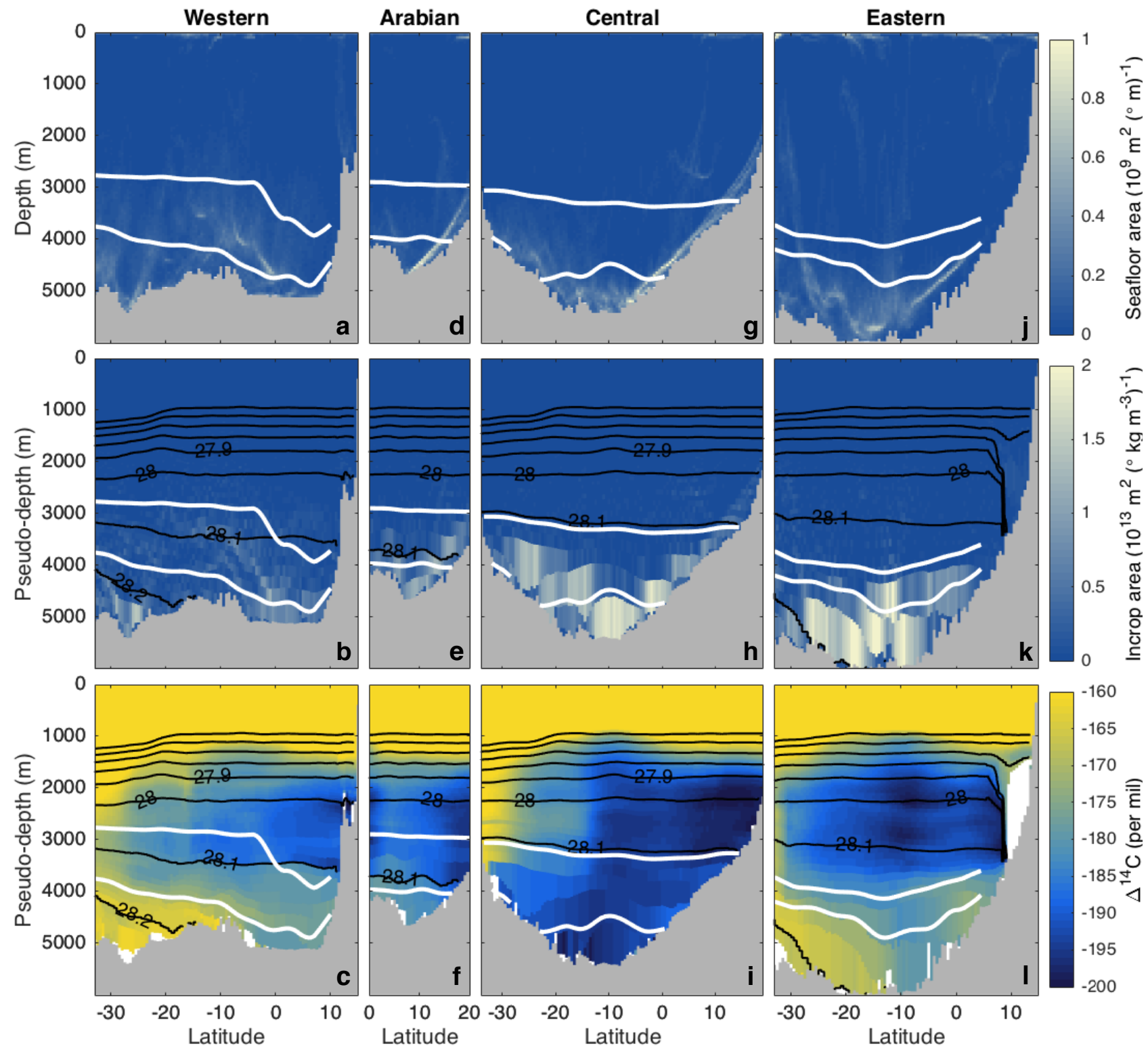


\section{ED Figure 4}
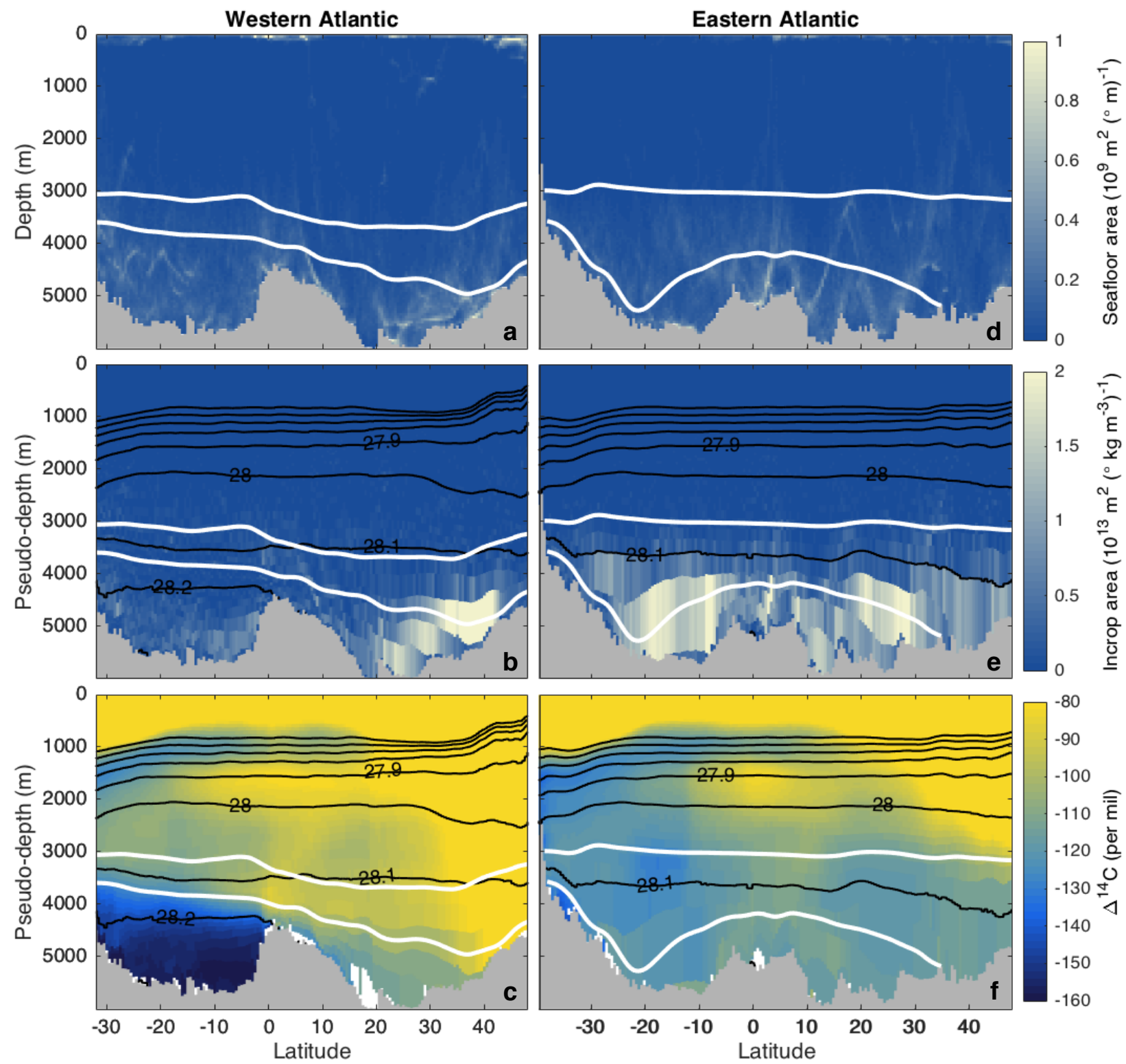
ED Figure 5
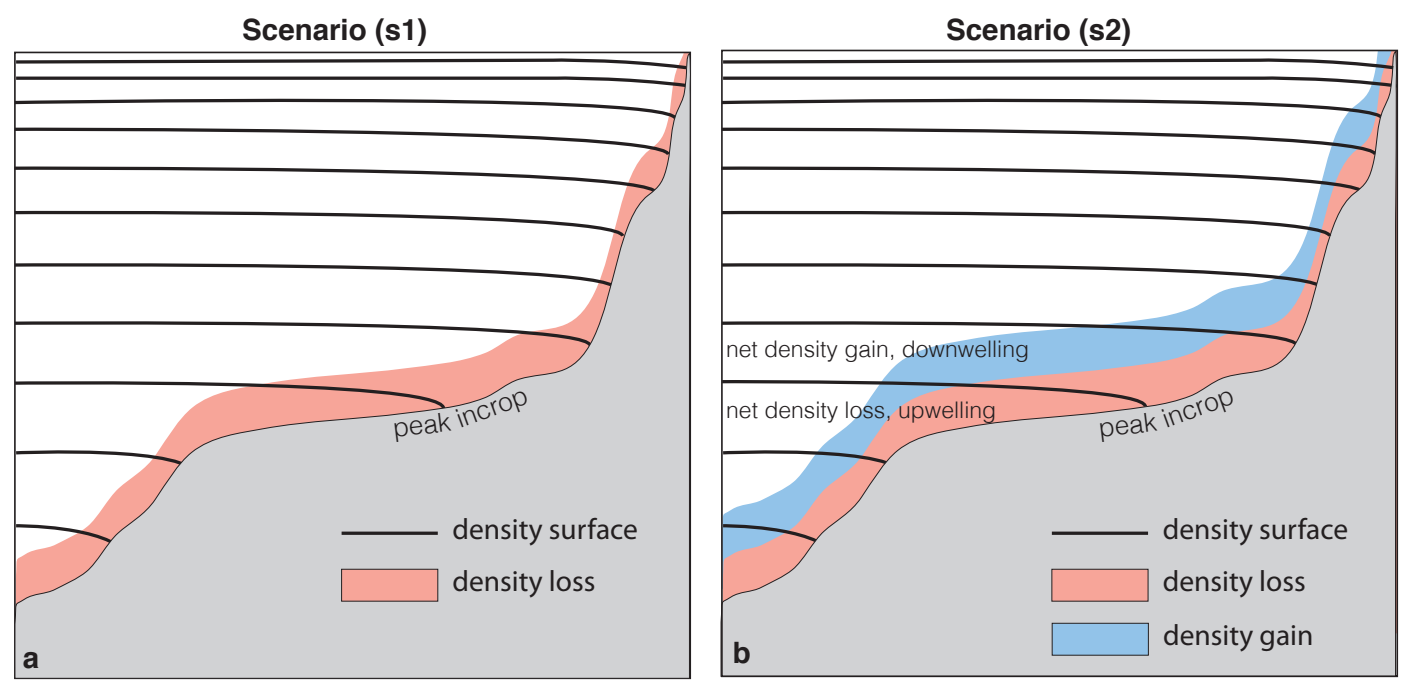


\section{ED Figure 6}

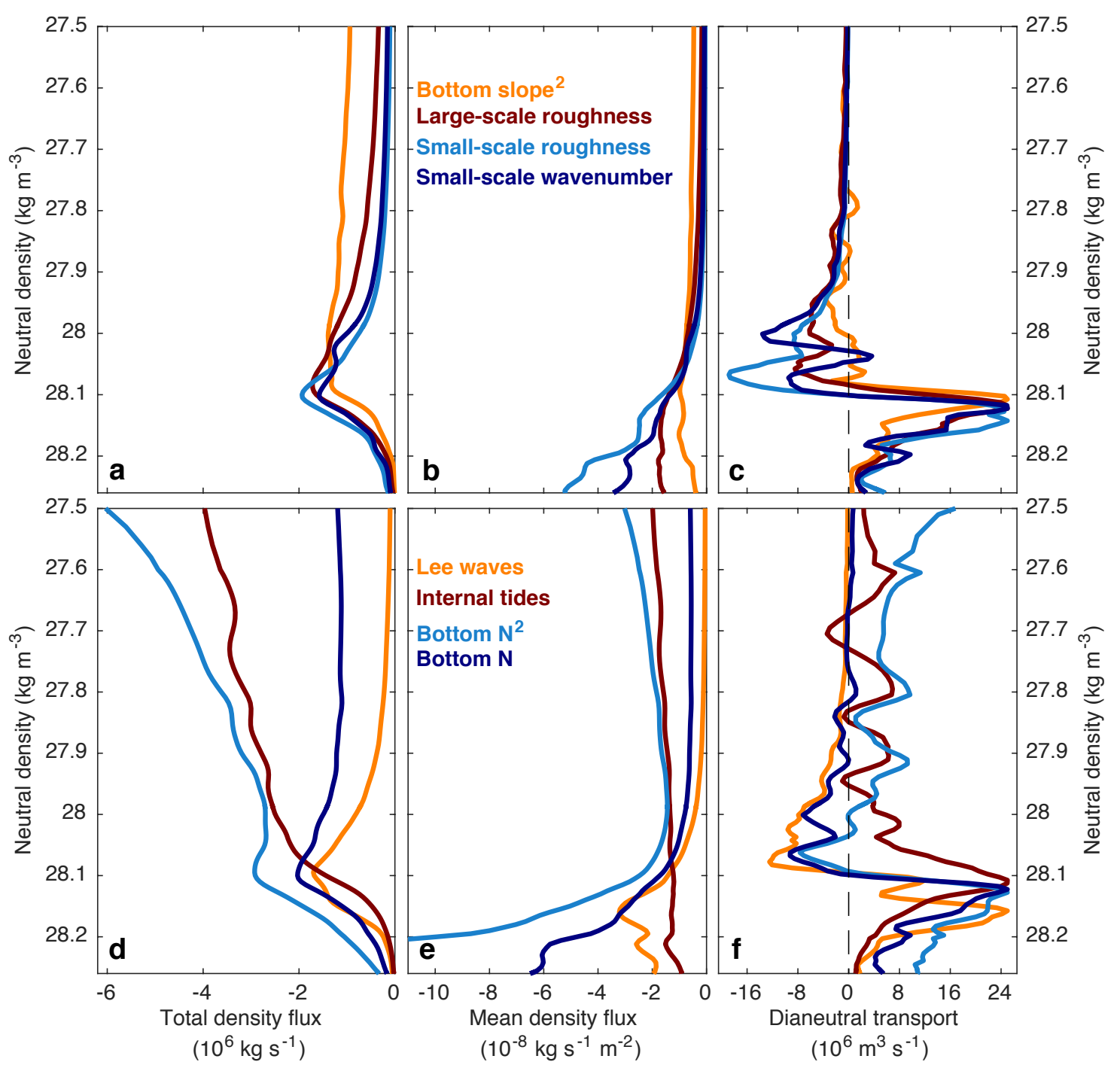




\section{ED Figure 7}
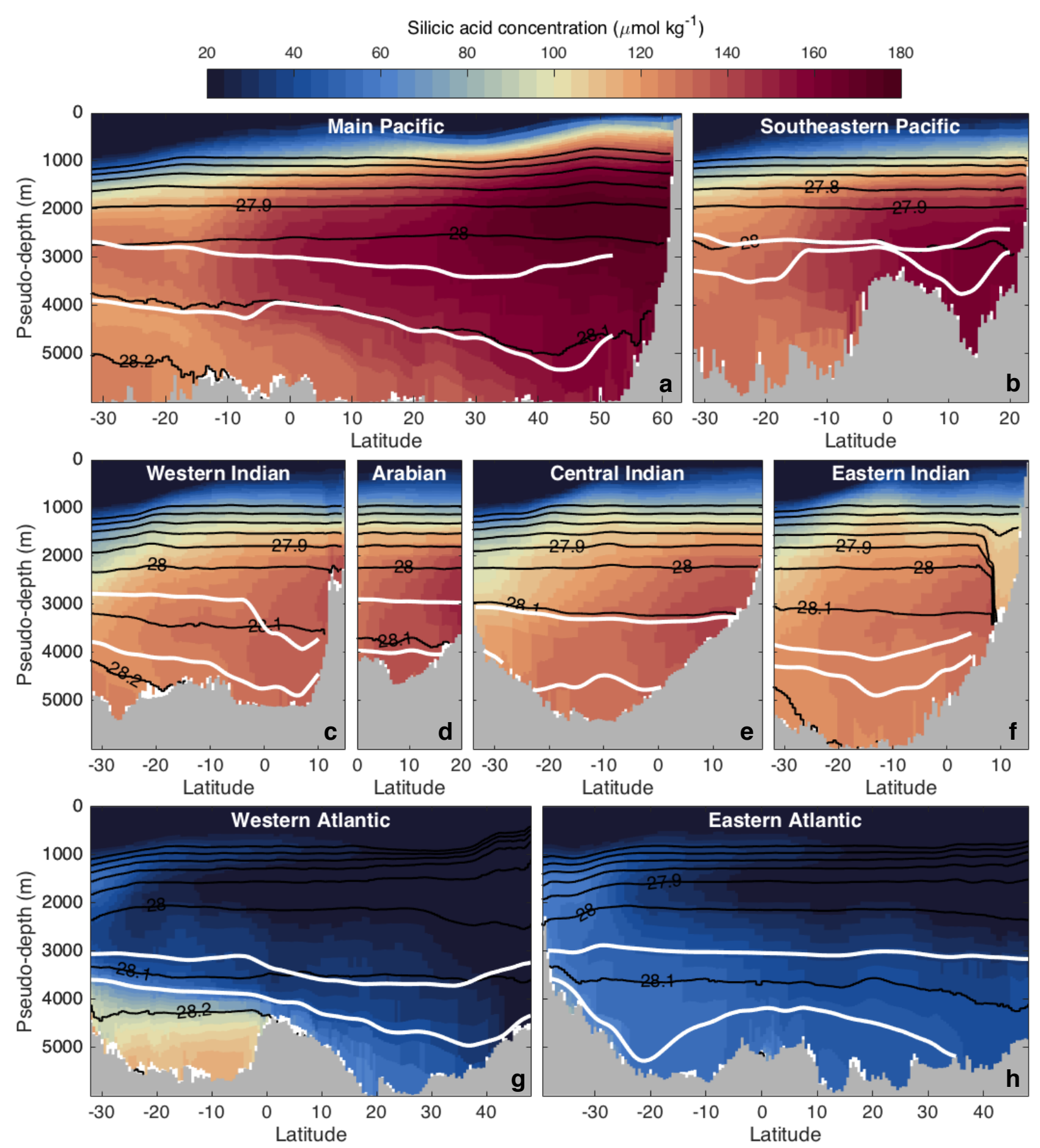


\section{ED Figure 8}

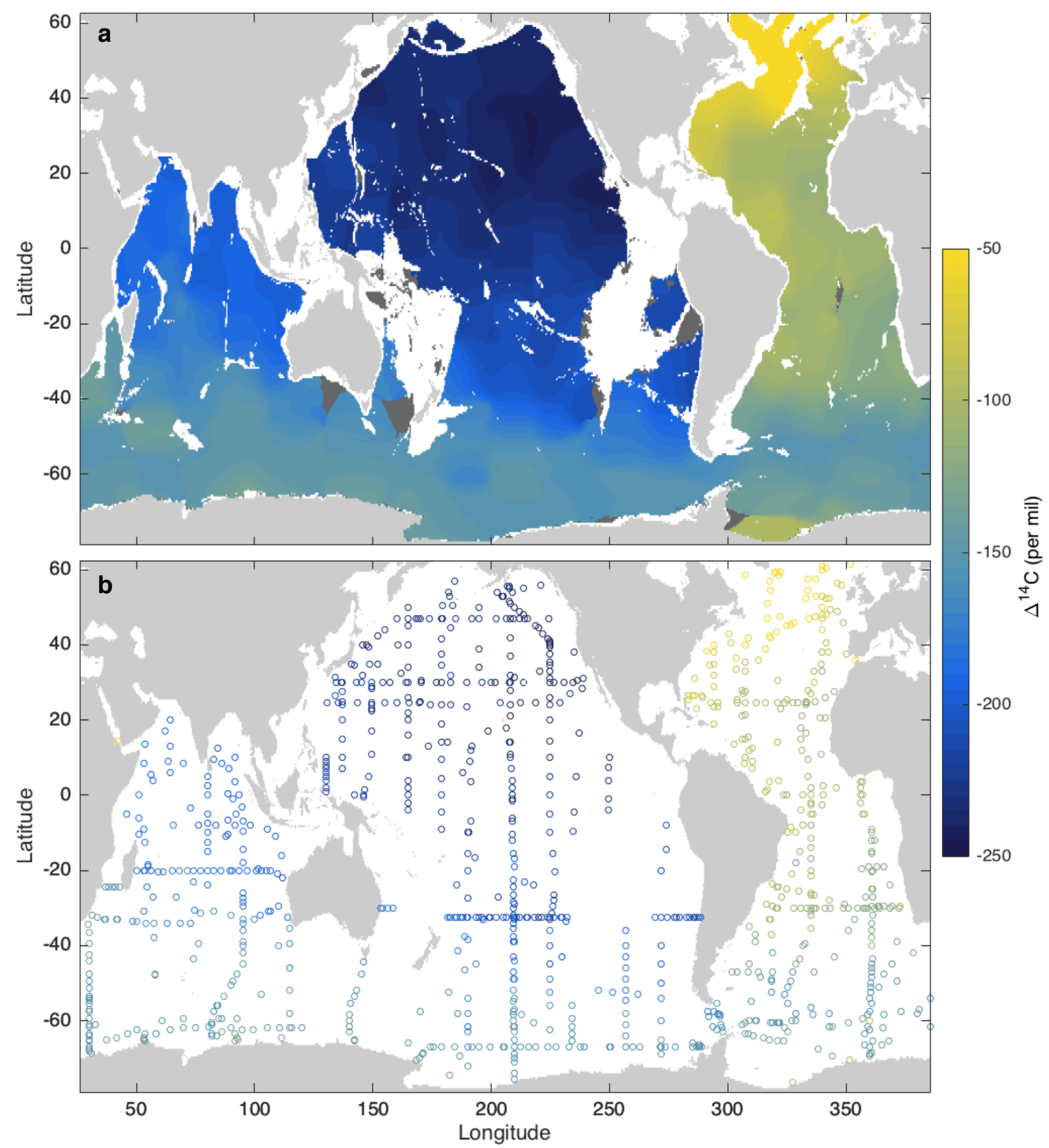


ED Figure 9

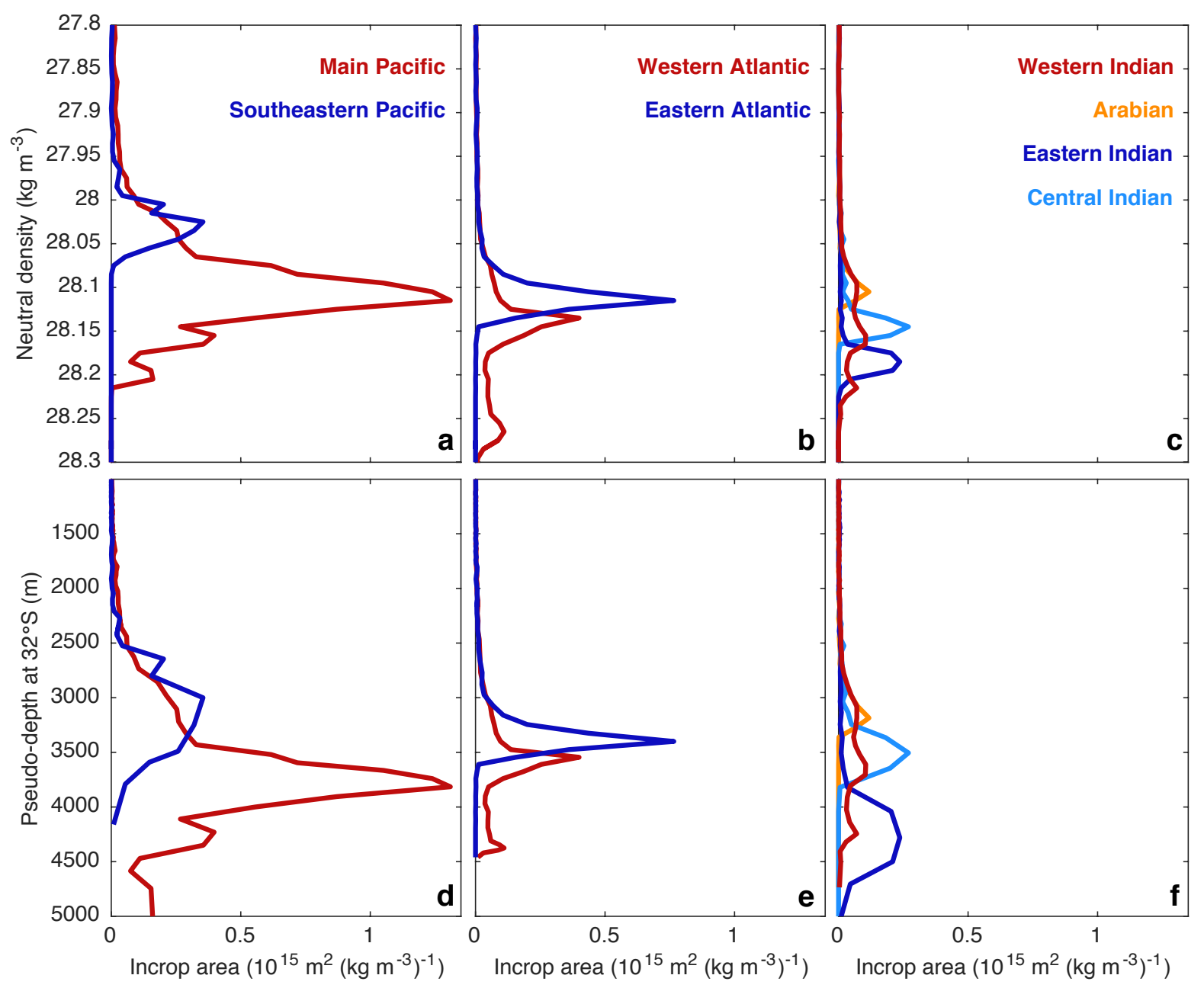

